\title{
THE AUTHENTIC CONSENT MODEL: CONTRACTARIANISM, CREDITORS' BARGAIN, AND CORPORATE LIQUIDATION
}

\author{
Rizwaan Jameel Mokal
}

(2001) 21 Legal Studies 400-443

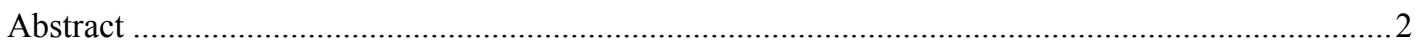

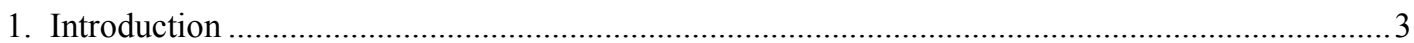

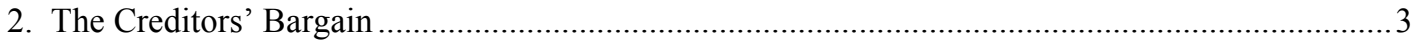

3. The Building Blocks Of The Bargain Model...........................................................................5

4. The Role Of Consent In The Bargain Model................................................................................. 8

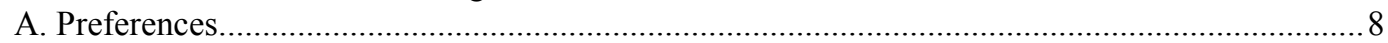

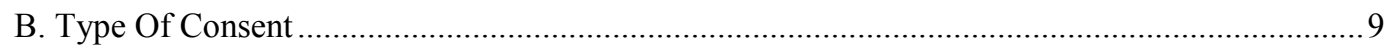

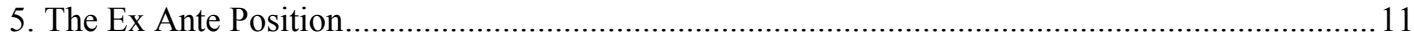

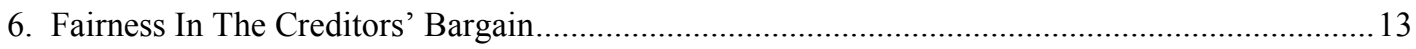

7. Preliminary Conclusions And A New Start ........................................................................... 15

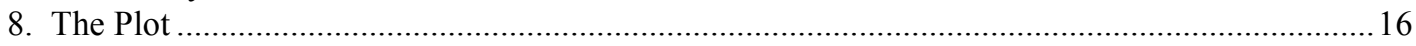

A. The Province Of Insolvency Law .................................................................................... 16

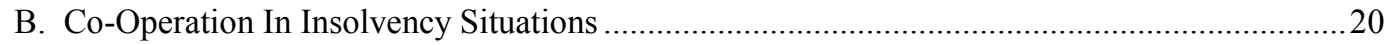

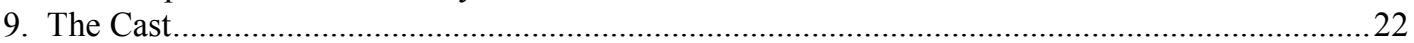

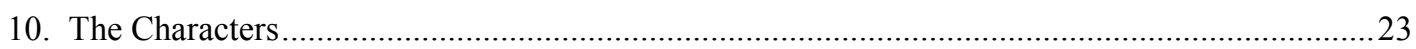

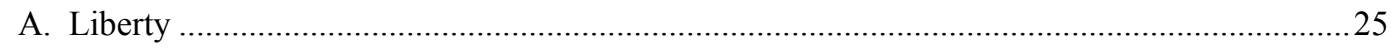

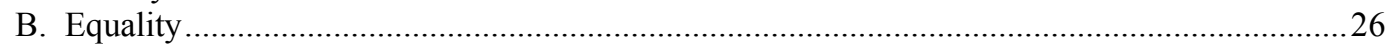

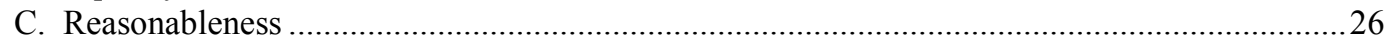

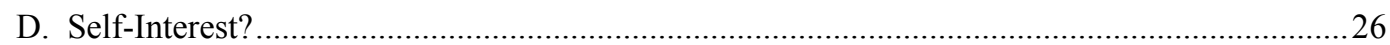

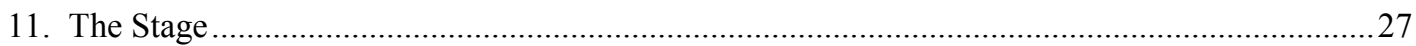

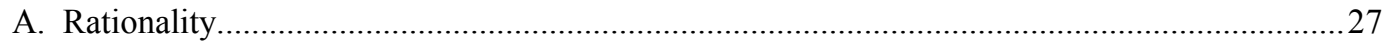

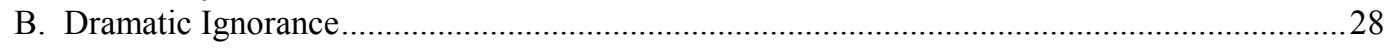

C. The Choice Position ........................................................................................................... 30

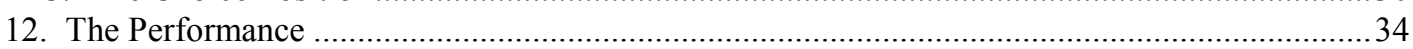

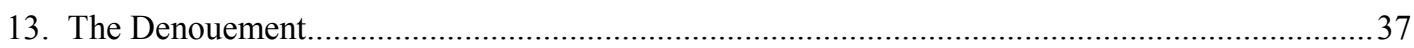

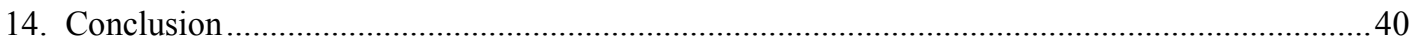

\footnotetext{
Barrister, Faculty of Laws, University College London. I am very grateful to Alison Clarke, and to John Armour, Stephen Guest, the participants of a staff seminar at the UCL Laws Faculty in February 2001, and an anonymous referee for their comments on earlier drafts of this article. Thanks also to Joseph Chun for many enlightening discussions on reciprocity and impartiality, and to Thomas Vial for invaluable help in navigating through the political philosophy literature. Any remaining shortcomings are mine alone.
} 


\section{ABSTRACT}

The first part of this article asks if the Creditors' Bargain Model, long employed by insolvency scholars as the starting point for many an analysis, can explain or justify even the most distinctive and fundamental feature of insolvency law. After examining the defining features of the model's construction, the role of self-interest and consent in it, and its ex ante position, it is concluded that the Bargain model can neither explain nor legitimate the coercive collective liquidation regime.

The second part of the article develops an alternative model to analyse and justify insolvency law. The starting premise is that all (but only) those affected by issues peculiarly governed by insolvency law are to be given a choice in selecting the principles which would determine their rights and obligations. Once these parties have been identified, they are to be given equal weight in the selection process, since their legal status (whether they are employees, secured or unsecured creditors, etc.), wealth, cognitive abilities, and bargaining strength, all are morally irrelevant in framing rules of justice. This part of the article introduces the notion of a constructive attribute, characteristics this society accepts its citizens should have in their role as legislators. So all parties affected by insolvency issues are regarded as free, equal, and reasonable. The model sketched out in this part of the article requires all principles to be selected from its choice position. Here, all the parties are deprived of any knowledge of personal attributes, and must reason rationally. It is shown that parties in the choice position would in fact choose the principles laying down the automatic stay on unsecured claims. The article concludes with the demonstration that because of the construction of the choice position and the constructive attributes of the parties bargaining in it, the principles chosen are fair and just, and chosen in exercise of the parties' autonomy. As it happens, they are also efficient. 


\section{INTRODUCTION}

That the formal onset of insolvency has a dramatic impact on a company's general creditors has often been noted. When the company finds itself unable to pay its debts as they become due ${ }^{1}$ the freedom of action afforded to such creditors is dramatically curtailed. When the company is to be wound up compulsorily, the winding-up order automatically suspends ('stays') all proceedings against the company except by leave of the court, and any disposition of the company's property which has taken place between the winding-up petition and the order is rendered void. So is any attachment, sequestration, distress or execution against its estate. ${ }^{2}$ The winding-up order operates in favour of all those with interests in the company's undertaking, and its unsecured creditors and shareholders must make any claims against it only in the formal insolvency forum. ${ }^{3}$ Equally remarkably, such restrictions on the freedom of action of the creditors of bankrupts have been an ancient and constant feature of this area of the law. Parliament in 1543, in its first ever attempt to deal with insolvency issues, provided a mechanism whereby the creditors of a bankrupt were to receive the latter's assets in 'a portion rate and rate alike, according to the quantity of their debt'. ${ }^{4}$ Crucially, invoking this mechanism barred other creditors from pursuing individual strategies to collect on their debts indefinitely. ${ }^{5}$ And the law governing corporate bankrupts gained the same characteristic within a few years of the corporate form being made rather more widely available. $^{6}$

This article sets out to explore the collective liquidation regime defined by the automatic stay, this central and seemingly indispensable feature of insolvency law. Its focus is on corporate rather than personal bankruptcy, and its task is to analyse the deep structure of the principles supporting the automatic stay. Given that insolvency law has seemingly been wedded to some such principles throughout its existence, any attempt to understand this branch of the law which does not explain these principles must be considered a failure. And anyone seeking a justification for the distinctive features of this part of the law must begin by showing why the principles behind the stay are normatively attractive. To fail to understand, explain and justify the existence of the automatic stay is simply to fail to talk about insolvency law as we know it. The article begins by putting to this test the best-established model in insolvency scholarship. Can that model explain and justify the automatic stay?

\section{THE CREDITORS' BARGAIN}

There is little doubt the Creditors' Bargain heuristic dominates scholarship in this area. For almost two decades, insolvency scholars have either argued within its assumptions, or have proceeded by marking it their first (and often primary) target. Though currently rather

\footnotetext{
${ }^{1}$ Insolvency Act 1986 (hereafter 'IA') s 123.

2 IA, ss 130(2), 127-8. See also s 112.

3 IA, s 130(4).

434 \& 35 Hen VIII, c 4.

5 The bar on creditors' rights to pursue individual remedies is analytically quite distinct from the order in which they are paid under the collective regime; see Section 12, below. This issue is discussed in greater detail in Mokal 'Priority as Pathology' [2001] CLJ (November).

$67 \& 8$ Vict, c 110 (1844) removed the need to obtain letters of patent from the Crown before a company could be set up, while $25 \& 26$ Vict (1862), c 90 confirmed that the presentation of a windingup petition would cause all actions against the company to be suspended. See generally V Markham Lester Victorian Insolvency: Bankruptcy, Imprisonment for Debt, and Company Winding-Up in Nineteenth-Century England (Oxford: Clarendon, 1995), Ch 6.
} 
unfashionable, the model still constitutes the only sustained attempt at a principled analysis of the law governing bankrupt companies (and indeed individuals). And only it has offered anything akin to a coherent justification of the peculiarities of this branch of the law. Even those fundamentally opposed to the project of the Bargain model acknowledge that 'the articulation of alternative points of view has not been nearly so coherent and well focused'? In view of the pre-eminence of the Bargain tradition, this article begins by asking whether the explanation of the automatic stay given by those expounding the Bargain model is satisfactory. For this purpose, the work of Thomas Jackson is taken as paradigmatic. He is the progenitor of the model, and it is in his work (sometimes in collaboration with Douglas Baird and Robert Scott) that this model attains its complete and most refined form. ${ }^{8}$ However, it must be noted that all the criticisms made here of his work are equally applicable to all those who have written sympathetically within the Bargain tradition. ${ }^{9}$

The Bargain model is supposedly based on the hypothetical agreement of those who would turn out to be creditors of an insolvent company. If these people could come together ex ante, before any lending has taken place, it is claimed they would agree to give up their freedom of action, should their debtor become insolvent. They would realise that in such a situation, independent action to enforce individual claims would be wasteful for all of them as a group. It might be, for example, that the debtor's assets are more valuable if sold together as a going concern, than if they were disposed of piecemeal. But if the only way of pursuing claims that was on offer was the individualistic pre-insolvency one, claims would have to be met as and when they were brought. The result would be the inevitable dismantling of the company's estate, and the loss of any 'going concern surplus'. This loss would be suffered by all the creditors collectively.

What is more, an individualistic system puts a premium on 'racing' for the debtor's assets at the mere hint of its being in financial trouble. This is because under the individualistic regime, as already noted, claims are met in the order in which they are brought, and should the debtor end up insolvent, there would not be sufficient assets available to meet all claims. It follows those first at the finishing line might receive everything that was due to them, while others would get little or nothing. The creditors bargaining ex ante would be likely to consider this undesirable for at least two reasons. First, each of them would have to incur costs on monitoring the debtor's financial state. Any creditor who refused to do so would end up with nothing in the company's insolvency: he would not learn in good time of his debtor's being in financial distress and would as a result lose the race. But each creditor has a similar incentive to monitor the debtor, and no matter how high the monitoring costs incurred in aggregate by all the creditors, some of them would still end up with nothing. So the individualistic regime requires duplicative and wasteful behaviour. Second, some creditors might be risk averse. This means they would prefer a lower but more certain return on their loans, to a higher but riskier one. ${ }^{10}$ The individualistic regime ensures precisely the opposite.

\footnotetext{
7 Warren 'Bankruptcy policymaking in an imperfect world' (1993) 92 Michigan LR 336, 338. Warren is one of the leading critics of the Bargain heuristic.

8 Jackson 'Bankruptcy, non-bankruptcy entitlements, and the Creditors' Bargain' (1982) 91 Yale LJ 857; Jackson The Logic and Limits of Bankruptcy Law (Cambridge, Mass: Harvard Univ Press, 1986); D. Baird and Jackson 'Corporate reorganizations and the treatment of diverse ownership interests: A comment on adequate protection of secured creditors in bankruptcy' (1984) 51 U Chicago LR 97; Jackson and Scott 'On the nature of bankruptcy: An essay on bankruptcy sharing and the Creditors' Bargain' (1989) 75 Virginia LR 155. See also Baird 'Loss distribution, forum shopping, and bankruptcy: A reply to Warren' (1987) 54 U Chicago LR 775, 815.

9 The present author himself must accept some degree of culpability! See Mokal 'An agency cost analysis of the wrongful trading provision' [2000] CLJ 335.

10 On risk aversion generally, see Pindyck and Rubinfeld Microeconomics (New Jersey: Prentice-Hall, 1998) (4 ed), Ch 5.
} 
The Bargain model claims that driven by these considerations, all the creditors would agree to substitute a collective debt-enforcement regime for the individualistic one. This regime would ensure that in their debtor's insolvency, the creditors would lose the ability to pursue their claims independently. The collective system would remove the necessity of racing for the insolvent's assets by eliminating the 'first in time, first in priority' bias of the individualistic pre-insolvency set-up. All like claims would now be treated alike regardless of when they were brought, so creditors would no longer need to waste resources monitoring the debtor. For the same reason, they would now be able to expect a more certain (though for some of them, perhaps a lower) return on their loans. What is more, a rational decision might be made about whether the company's undertaking should be kept together, or broken up for sale. This would benefit all those with rights against the company's property.

This, then, is the basic insight offered by the Creditors' Bargain. The collective regime defined by the automatic stay would be voluntarily selected by the creditors subject to its coercion, if such creditors could decide ex ante what should happen in their debtor's insolvency. But creditors can not meet with each other in this way in real life because it is difficult to predict ex ante who would lend to a company during its existence, and who would have claims outstanding when the company becomes insolvent. So the Bargain model predicts what real-life creditors would agree to if they could meet and negotiate with each other and if there were no transaction costs, and the mandatory automatic stay merely enforces that hypothetical bargain. ${ }^{11}$

Jackson believes his model is 'an application of the famous Rawlsian notion of bargaining in the "original position" behind a "veil of ignorance"". ${ }^{12}$ But it will be argued that Jackson's theory has little to do with Rawls. In fact, the building blocks of this theory are decidedly non-Rawlsian, and are inspired instead by an alternative 'contractarian' approach (so called because it claims to derive its explanatory force from some sort of agreement) developed by Richard Posner shortly before Jackson first expounded the bargain. ${ }^{13}$ Apart from the fact that both Rawls' and Posner's (hence Jackson's) theories are contractarian, they have nothing in common. This has profound implications for the Bargain model.

The Creditors' Bargain can be analysed in terms of four elements. The first two concern the nature of the participants in the bargain. The third is the notion of consent (hence the 'bargain' terminology), and the final element is the ex ante position where the negotiations take place (this is supposedly the model's version of the Rawlsian 'original position'). These elements are examined in turn below.

\section{THE BUILDING BLOCKS OF THE BARGAIN MODEL}

It is quite crucial to be clear about the identity of the actors in Jackson's model. Note first of all that in the Creditors' Bargain, the bargain is hypothetical, but the creditors are quite real. The argument is that actual creditors in a (or any) real-life transaction, if allowed to haggle with each other before anyone lends anything, would agree to the collective regime. '[The] hypothetical bargain analysis provides indirect evidence of what real world parties would, in fact, agree to. ${ }^{14}$ So the notional bargain would have been concluded by 'actual people, deploying actual endowments of skill and energy and character, making choices under

\footnotetext{
11 This summarises the arguments in Jackson Bankruptcy, Ch 2.

12 Ibid, p 17 fn 22; see pp 236-7.

13 Posner 'The ethical and political basis of the efficiency norm in common law adjudication' (1980) 8 Hofstra LR 487.

14 Jackson and Scott 'Nature', p 160 (emphasis added).
} 
uncertainty'. ${ }^{15}$ This means participants in the Creditors' Bargain have the sort of attributes that creditors in real-life transactions have. The various parties who give consent here lend either secured or unsecured, are 'systematically faster... or friendlier with Debtor' than others, and are able to affect the (notional) bargaining process differently according to their 'relative savvy and bargaining skills'. ${ }^{16}$ Let us call this the Real Parties premise.

These 'real world parties' must together make a (hypothetical) choice of the governing insolvency principles. This choice is restricted only by the 'natural ignorance' of the eventual outcome of their transactions with the debtor. ${ }^{17}$ Let us designate this the Natural Ignorance premise. Importantly, creditors continue to have, and know they have, all the various attributes that make them different from each other at the time that the notional bargain is to be concluded. ${ }^{18}$

Note that in a way, Natural Ignorance is quite an unsurprising condition. It demands that before being asked (notionally) to consent to the automatic stay, creditors should be denied knowledge of what would happen to their particular debtor. They should not know if the latter would become insolvent while still indebted to them. They should not be aware of how well-positioned they would be in this particular transaction to win an individual race to the court in order to obtain a judgment and enforce it against the debtor's assets, if there is no collective insolvency regime and this debtor gets into difficulties. But as already noted, they should continue to be aware of who they are, of whether they are systematically faster than other creditors in this particular transaction, of whether they have inside knowledge of the debtor's business affairs by virtue of being one of its directors, etc. The creditors' ignorance is 'natural' because it is precisely the sort real creditors at some actual pre-transaction stage could be expected to be in, no more and no less.

Strangely, though, it might be (and has been) objected that to impose this condition on Jackson's model is to construct a man of straw which might eventually prove easier to knock down. It might be claimed that Natural Ignorance is too harsh a restriction to impose on the model, and can not be regarded as necessary to a faithful reading of it. In particular, what the creditors know about themselves in the ex ante position should be construed otherwise than by way of this condition.

The objection, which will be explained in more detail below, has been put to the present author a number of times, and appears to those making it to be very straight-forward indeed. In reality, it is a complex one, and can only be met through some understanding of the philosophical underpinnings of the Bargain model. Its significance will become increasingly apparent as the argument progresses, and it will decisively be shown to be untenable only towards the end of this article. ${ }^{19}$ But a start can be made in that direction now. Here are a couple of preliminary points. Natural Ignorance requires creditors to know who they are, how good are their debt-collection skills, and how they are related to the debtor. Note first of all that this is the only form of restriction on the creditors' knowledge compatible with the actual text of Jackson's (and Scott's) argument. Any other reading simply ignores the repeated and emphatic reliance placed by its creators on this element of the model. Jackson's argument is replete with references to the knowledge the negotiating creditors have of their own abilities and characteristics. ${ }^{20}$

\footnotetext{
15 Posner 'Efficiency', p 499.

16 Jackson Bankruptcy, pp 59 fn 80, 15 and 30 respectively.

17 Posner 'Efficiency', p 499.

18 Jackson and Scott 'Nature', p 160; see also the references from Jackson Bankruptcy, above.

19 See Section 13, 'The Denouement'.

20 See again Jackson and Scott 'Nature', p 160 and Jackson Bankruptcy, pp 59 fn 80, 15 and 30, etc. See also Posner 'Efficiency', p 499. These examples are merely illustrative, not exhaustive.
} 
And second, there are substantive internal reasons for saying Jackson regards Natural Ignorance as a mainstay of his theory. His treatment of tort creditors is an example. Natural Ignorance requires that the participants in the bargain be aware of personal attributes, but unaware of the contingencies which would eventually arise from the operation of the debtor's business. On this view, victims of the debtor's tort who would have claims outstanding against it when it becomes insolvent, should have no place in the hypothetical ex ante bargain, since their status qua creditor arises precisely from the operation of the debtor's business. Now it would seemingly be easy for the proponents of the Bargain model to argue that tort creditors too be consulted hypothetically at the pre-transaction stage when the bargain is concluded. But this would violate the Natural Ignorance condition, and if true to its premises, the Bargain model should resist the temptation of attaining this otherwise desirable extension of its scope (to include within its explanatory and justificatory ambit this type of creditor as well). And in fact, Jackson states that:

'[Whatever] the merits of the claim that society owes [tort] victims protection[,] this protection does not derive from the consensual arrangements that would underlie any ex ante creditors' bargain. Distributions to nonconsensual claimants are conceptually different from those that would be agreed to in any bargain in which individual selfinterest was a central feature. ${ }^{21}$

Now of course if non-consensual claimants were to be given a say in the ex ante bargain, then it would hardly be surprising to find the rules chosen in it provided for distributions to them, precisely because individual self-interest was a central feature of the mode of selection of those rules. (X, a tort claimant-to-be, would demand at the pre-transaction stage that his interests be taken into account, should the debtor company become insolvent.) And yet the expositors of the model decisively reject any suggestion that such claimants be given locus standi in the hypothetical agreement. Nor is this failure to include simply a matter of oversight. It is not that this move - hypothetically asking future tort creditors the question 'How would you like to be treated in your debtor's insolvency?' -- just never occurred to those expounding the Bargain model! As noted, Jackson and Scott explicitly consider and reject the suggestion, on the basis that the inclusion would be conceptually inconsistent with their model. In fact, the only way to explain Jackson's refusal to extend his model to include tort creditors at the ex ante stage is to point to the strict adherence on his part to the requirements of Natural Ignorance. Such adherence is not merely accidental or incidental. Jackson and Scott insist it is a 'central premise' of the bargain. ${ }^{22}$ We must take them at their word. ${ }^{23}$

\footnotetext{
${ }^{21}$ Jackson and Scott 'Nature', p 178 (emphasis added).

${ }^{22}$ Ibid, p 160.

${ }^{23}$ In view of these preliminary points, and those to be made later, it might be observed those objecting to the view that Natural Ignorance is central to the Bargain model are sympathetic indeed towards that model, hoping to save Jackson and Scott from their own folly by suggesting an alternative reading, one which might override the manifest intentions of the model's expositors but which the objectors consider more viable nonetheless. Alternatively and less kindly, it might be said such objectors have paid insufficient attention to the details of the model's construction, or to its philosophical basis. As it happens, those denying any necessary link between the model and Natural Ignorance do not generally appear too sympathetic towards Jackson's (and Scott's) project as a whole.
} 


\section{THE ROLE OF CONSENT IN THE BARGAIN MODEL ${ }^{24}$}

The principle of consent has great intuitive appeal in normative theory. The fact that one has agreed to accept a particular obligation, or to the application to his situation of a certain policy, is a good moral reason for enforcing that obligation against him or applying that policy to him. If actual consent is for some reason unobtainable, then it is argued 'implied' consent may be relied upon to the same effect. ${ }^{25}$ The Creditors' Bargain repeatedly invokes some sort of consent on part of creditors to justify some or other aspect of insolvency law. ${ }^{26}$ But the principle of consent is notoriously deceptive. ${ }^{27}$ So this Section seeks to determine the precise nature of the consent at play here. The issue is approached from two directions. First, what sort of propositions are the creditors being asked to consent to? And second, how is it determined whether creditors have consented to those propositions?

\section{a. Preferences}

So, what sort of propositions are being put to the creditors for approval at the hypothetical negotiations? Suppose a choice must be made between Rules P and Q. Rule P lays down that in a company's insolvency, its unsecured creditors would lose the ability individually to proceed against it, and a collective regime would take over. Rule Q, on the other hand, allows the pre-insolvency 'first come, first served' system to continue to prevail. X Ltd. is a weak, over-stretched trade creditor. It anticipates that it would not have enough resources to expend on monitoring its debtors' prospects and financial health, and that it is likely to be beaten in most individualistic races for the debtors' assets by better-resourced competitors, should any of its debtors become insolvent. Suppose that $\mathrm{X}$ is asked to express a preference between Rules $\mathrm{P}$ and $\mathrm{Q}$, based on whatever considerations appeal to it. It is obvious $\mathrm{X}$ has strong reasons of self-interest for supporting $\mathrm{P}$, and little reason for choosing $\mathrm{Q}$. So Rule $\mathrm{P}$ is applied to all transactions. $\mathrm{X}$ is now taken over by a large conglomerate, and finds it has plenty of resources at its disposal to divert to remaining abreast of its debtors' financial health. Realising it can ensure a place at the head of the queue for the assets of most of its insolvent debtors in an individualistic regime, $\mathrm{X}$ now indicates it wishes to change its preference, opting (as could be expected) for Rule Q. How does the Creditors' Bargain deal with this request?

The challenge posed by this thought experiment to the Bargain model may not be immediately obvious. The model seeks to justify the mandatory automatic stay on unsecured claims by suggesting the creditors themselves would accept that regime, if only they could be consulted before lending anything. The problem, though, is that there is nothing within the model to suggest preferences expressed at a time $\mathrm{t} 1$ should be any more binding than those revealed at a later time $\mathrm{t} 2$. Now, if the creditors were being asked to choose a just or fair system for governing unsecured claims in their debtor's insolvency, or even an efficient one, then (in our example) X's change of mind would smack of hypocrisy and Jackson could recommend that X's request be rejected. ${ }^{28}$ But crucially, the bargain is supposed to be based solely on unconstrained choices, and more specifically (as discussed in the next Section), on one's self-interest.

\footnotetext{
${ }^{24}$ The arguments in Sections 4 and 5 draw frequently on Dworkin 'Why efficiency?' (1980) 8 Hofstra LR 563, Brudney 'Hypothetical consent and moral force' (1991) 10 Law and Philosophy 235, and Hardin 'The morality of Law and Economics' (1992) 11 Law and Philosophy 331.

${ }^{25}$ Posner 'Efficiency' p 494.

${ }_{27}^{26}$ See eg Jackson Bankruptcy, pp 13, 15, 17 fn 22, etc.

${ }^{27}$ See eg Hardin 'Morality' 361.

${ }^{28}$ Brudney 'Consent', pp 239-40, considers a similar argument.
} 
It is important to understand why this is the case. Remember that Jackson's theory is an 'economic' model, i.e. based on the tenets of Law and Economics, and therefore on a particular view of neo-classical microeconomics. And the latter in turn revolves around individuals revealing preferences in the market. The argument in microeconomics often is that despite being guided by nothing but rational self-interest, and given conditions of complete markets, sufficient competition, information and resource flows etc., the preferences expressed by the individual participants in the market ensure that the market tends towards efficient equilibrium (which is taken to be a desirable state of affairs). The argument derives its force from its demonstration that no appeal to notions like 'morality', 'justice', or 'fairness' is required for (desirable) efficiency to be attained. Here, individuals are not deliberately making efficient choices (or 'fair' ones, whatever that might mean in this context).

So the Bargain model is based on nothing but self-interested preferences. Jackson nowhere even hints that anything else at all motivates the creditors' choices. ${ }^{29}$ But the problem is that, in our example, $\mathrm{X}$ Ltd. has an equal incentive to express contradictory choices at different points in time, both driven by exactly the same motivation. So why should the choice made at time $\mathrm{t} 1$ be reified in the law, while the contrary one made at $\mathrm{t} 2$ is simply ignored? Someone might wish to reply that the choice at time tl would have encouraged legitimate expectations about how future transactions would be dealt with, so it should be held binding. But this reply misses the point. The order of choices is arbitrary and could be reversed (a rich creditor which had chosen the individualistic regime at $\mathrm{t} 1$ is newlyimpoverished and now wishes to choose the collective one). In that case, the Bargain model should insist the reified choice is the one in favour of the individualistic regime, hence providing no support for our collective system. Or it might be stipulated that the choice made at time $\mathrm{t} 2$ should only affect transactions taking place at $\mathrm{t} 3$, $\mathrm{t} 4$, etc. Since there would be no retroactivity, there could be no confounded expectations, and the automatic stay could be abandoned thenceforth for the free-for-all system.

The point should be somewhat clearer now. The Creditors' Bargain model is based on the preferences it claims would be revealed by creditors at a hypothetical pre-transaction stage. But those preferences are shaped by nothing except individual self-interest, and creditors could be expected to express different preferences at different times. If the parties' self-interest shifts, for example, so would their preferences. If true to its premises, the model should then recommend that so should the law. Such a chameleon-like law is not our law (nor should it be), and the Creditors' Bargain model provides no justification for the compulsory collective forum marked by the automatic stay.

\section{b. Type of consent}

Perhaps we are being too hasty. Perhaps the ex ante position of the model, to be considered later, provides a uniquely privileged point in time, so that even mere preferences revealed then ought to be considered binding. So let us leave this argument for the moment, and move on to consider the type of consent employed by the Bargain model. A four-fold classification is convenient for our purposes. ${ }^{30}$ The argument which follows is not based on isolating varieties of consent which are somehow essentially and necessarily distinct. It simply identifies four points on a continuum, and there will inevitably be some overlap between 'adjacent' categories. Suppose A and B negotiate with each other freely, acquire and share all

\footnotetext{
${ }^{29}$ No reference can be made to Jackson's work here since the text asserts a negative. So the reader is invited to consult Jackson's work and confirm none of his substantive arguments turns on anything but self-interest.

${ }^{30}$ Dworkin 'Efficiency', p 577, and Brudney 'Consent', pp 263-8.
} 
the relevant information, and then enter into a contract of sale. They can then be taken to have given express consent to the terms of that agreement, and those terms may legitimately be held against either one at a later date. But of course consent of this sort has no role to play in the Creditors' Bargain. The latter is based on the very premise that it would be impractical to get such consent from all the creditors, not least because it would be prohibitively expensive to identify all the parties who would lend to a particular debtor during the latter's lifetime, and who would have claims outstanding when the latter becomes insolvent.

Suppose now that after A and B concluded their agreement, there arose a dispute about an issue not explicitly discussed in its text. But assume further that both A and B had thought about that issue themselves while the agreement was being negotiated, and had each reached the independent conclusion that any such dispute would and ought to be resolved by applying Rule X (for the sake of simplicity, say each wrote a note to herself to this effect at that time). In this case, Rule X has received unexpressed consent from both parties, and it would be fair to hold them to it later. But again, the Creditors' Bargain can not be relying on unexpressed consent to the automatic stay, since it would stretch credulity too far to assume all creditors affected by the stay had in fact thought about and somehow accepted it in their mind. At the very least, the Bargain model presents no evidence in support of any such claim.

Next comes reconstructed consent. Suppose A and B disagree about the currency in which payment for their contract should be made. But neither thought about or brought up this issue during their negotiations. As it happens, though, both operate in an industry where (unless otherwise agreed), the payment is always made in the seller's currency. So scrupulously is this practice adhered to, in fact, that a reasonable person in either party's shoes would expect her dealings also to be subject to it, and in entering into the transaction nonetheless without stating otherwise, could be taken to have consented to it. In this case, A and B can legitimately be held to have given reconstructed consent to the seller's-currency 'rule', which might be enforced against either one.

Yet again, though, the Creditors' Bargain could not be relying on this variety of consent. Note that in our example, A and B belong to a particular commercial community, and it is only by virtue of this that the community's practices can be held applicable to them. The community already exists, and its customs (or at least some of them) are already accepted as legitimate. The reasonable person said to be able to anticipate the application of such a custom to her situation is 'reasonable' precisely because her expectations are consistent with what that community finds acceptable. But what if the existence of the custom, rule or practice itself - and not merely its application to some situation - stands in need of justification? Suppose it is argued that the seller's-currency rule is justified because A has given it reconstructed consent. And we know A has given such consent because a reasonable person in her shoes would have consented to that rule. But the reasonable person can only be said to have consented to the rule because both the existence of the rule, and its legitimacy, are already being assumed (or are being demonstrated elsewhere). So this attempt to justify the rule itself simply begs the question. Similarly, since the Creditors' Bargain is supposed to justify the very institution of insolvency law, and in particular of the stay on unsecured claims in a company's insolvency, it can make no appeal to reconstructed consent.

We come finally to counterfactual consent. The label itself indicates that if $\mathrm{X}$ is said to have given counterfactual consent to a rule, then he has not in fact consented to it. '[C]ounterfactual consent is not some pale form of consent. It is no consent at all. ${ }^{31}$ The argument here really is that the rule should be applied to X quite independently of whether he has consented to it, and the latter is merely the facade behind which the real work is done. Consent here is a rhetorical device; the force of the argument lies elsewhere.

${ }^{31}$ Dworkin 'Efficiency', p 578. 
How would one argue that X should be taken counterfactually to have consented to a policy or rule? One popular approach is to suggest the policy is in X's self-interest. So if given the opportunity, he would freely accept it. This form of argument is very common to much of Law and Economics where appeal is made to consent. ${ }^{32}$ It is also at the core of the Bargain model. Recall the discussion above. Since the collective liquidation regime characterised by the automatic stay is so clearly in the common interest of creditors, it seems only reasonable to conclude they would have consented to it, if asked in advance.

Note though that what is in X's self-interest is a function of knowledge. This might seem strange, but is in fact fairly straight-forward. Suppose $\mathrm{X}$ is risk-preferring, and proposes to buy a ticket in a fair lottery at time $t 1$. At $t 2$, he actually buys the ticket, and at $t 3$, he discovers his ticket has lost. Now given X's attitude to risk, buying the ticket increases his utility and was in his interest ex ante, before the lottery took place. But this is premised on $\mathrm{X}$ having no more than the knowledge he did in fact have at $\mathrm{t}$. Had X somehow discovered then (at $\mathrm{t} 1$ ) that the ticket he was buying would lose, the purchase would not have been in his interest.

So it is crucial in any argument based on self-interest to specify when the calculation of self-interest is to be made, and how much is known about the world at that point. The automatic stay might be in X's self-interest before it becomes clear (to X himself or 'objectively') how advantageous a position he would be in to grab his debtor's assets when the latter becomes insolvent. The stay would not be in X's interest once it became known X was ahead of fellow creditors, and would in fact have been able to claim back all he was owed, had the 'grab rule' continued to govern. ${ }^{33}$ The Bargain model is based on the creditors' self-interest. But that self-interest depends on what is known about circumstances relevant both to the transaction, and to the actor whose interest is being calculated. So, at what point in time -- or what is the same thing, at what state of knowledge -- does the model determine the parties' interest? And why is that point of time, or that state of knowledge, privileged, so that any choice then made ought to be considered binding?

\section{THE EX ANTE POSITION}

The bargain is to be concluded before any lending has taken place, and the parties are unsure how they would fare under any regime picked to govern the situation, should their debtor become insolvent. This is the model's ex ante position, and it is crucial in generating normative appeal. The argument seems to be that since creditors do not know how wellplaced they would be to race for the debtor's assets, they can not bias the selection process so as to produce principles favouring them at the expense of others. But recall that in the terms adopted above, the bargaining creditors are Real Parties in Natural Ignorance. They might not know how a particular transaction is going to turn out, but they are aware of whether they are systematically faster than their competitors, or of whether they wield special influence over the debtor, etc. Keeping in mind these defining features of the ex ante position, let us examine the two closely-related ways in which the position can be interpreted. On either view, does the Bargain model predict that all creditors equally would accept the automatic stay?

\footnotetext{
32 Posner 'Efficiency', p 492 and the references cited therein; see also Mokal 'Wrongful trading'.

33 Under the collective regime, of course, he would have to accept whatever priority was given to his 'type' of creditor by insolvency law; see Mokal 'Priority as Pathology'. Note also that this simple example is based on a transaction-specific view. The argument is broadened in the next Section to include the long-term interests of creditors.
} 
On the first interpretation, we focus on the perspective of a single creditor and ask whether the stay would be acceptable to him. Take C Ltd., a trade creditor newly entering into business. Suppose that of the first ten loans it makes, five have to be collected through court proceedings, and three of these debtors go into insolvent liquidation. C's employees are still learning to work as a team, and its finance director is inexperienced in ordinary (noninsolvency) debt-collection procedures. Before extending credit each of these ten times, C would have calculated that the automatic stay was in fact in its interest, since it could not hope to compete against more experienced actors who could also be expected to lend to its creditors. Of the next ten loans made by $\mathrm{C}$, five again turn out to be troublesome, and require litigation. Yet again, three of these debtors become insolvent. By now, though, C's employees are proficient, and its finance director can rely on them to ensure claims will be speedily filed, and judgments enforced faster by $\mathrm{C}$ than by most competing creditors. For these transactions, $C$ regards the individualistic regime to be in its interest. Now, the Bargain model's fundamental premises require 'actual people, deploying actual endowments of skill' to make the calculation of self-interest. So we must ask $\mathrm{C}$ whether it finds the stay acceptable. But what is the correct ex ante position in which this calculation is to be made? Is it before C's first loan, when $\mathrm{C}$ is a new-comer to the business? Or after its tenth loan, or its tenth bad loan? The choice of the ex ante position makes all the difference. And yet there is nothing in the model to help us choose between the various ones on offer. It is not just that the model does not predict the principles governing the automatic stay; in fact, the model's predictions are quite indeterminate.

This leads us to the second interpretation of the ex ante position. Here, we focus not on one creditor over a series of transactions, but on all the creditors in a (or any) transaction. If asked before anyone has lent anything, would all the creditors accept the stay? Take again C Ltd. as it is after having lent a number of times and having dealt with the consequences, a consummate collector of debts, lining up once again to extend credit. Imagine also E, F and $\mathrm{G}$, highly-skilled computer engineers who work for the debtor-to-be at a time when there are plenty of such engineers in the labour market, and who have never before had to resort to legal action to collect debts. Though they do not know it yet, they will become creditors for back pay and accrued holiday remuneration, etc. Now the creditors must determine what is in their interest. It should be clear by now this calculation is affected not only by how much is known of a creditor's immediate circumstances (e.g. how well-positioned $\mathrm{C}$ is in this transaction to grab the insolvent's assets), but also by what is known of his attributes (that $\mathrm{C}$ is a repeat player with accumulated expertise for collecting debts) and those of his competitors (that $\mathrm{E}, \mathrm{F}$ and $\mathrm{G}$ do not have such skills). Given that all the parties bargaining ex ante are aware of these facts, no agreement would be concluded. $\mathrm{C}$ would insist on a free-forall system, while E, F and G would hold out for the stay on all claims.

It seems then that the Bargain model does not predict what it is supposed to. Creditors consulted ex ante (on either interpretation of this concept) would be unable to agree on how their claims should be dealt with in their debtor's insolvency. What is worse (recalling the discussion from the previous Section), we have still found nothing in the model to indicate the parties are supposed to express anything but mere preferences. So not only will agreement not be reached in a particular transaction, but the choices made in the ex ante position of one transaction could permissibly be altered in the next. This ensures that no agreement would ever be attained in the ex ante position of any transaction. Creditors with a better than average chance of winning the race to grab their debtor's assets simply have no incentive to give up that chance, unless they were ensured correspondingly superior rights within the collective insolvency regime. But nothing in Jackson's model argues for that result. $^{34}$

\footnotetext{
${ }^{34}$ In fact, he supports the pari passu principle for unsecured creditors; see Bankruptcy, pp 30-1.
} 
Jackson is aware of the problem. He acknowledges that his model predicts the collective system would only be acceptable to 'a homogenous pool of creditors' ${ }^{35}$ In fact, in predicting the automatic stay, the Bargain heuristic is forced numerous times to assume all creditors are homogenous in terms of their ability to collect debt, and to influence the debtor. ${ }^{36}$ But of course they are not, and Jackson must explain why making the assumption of creditor homogeneity has no effect on the model's analytic and justificatory efficacy. Obviously, if his model can only predict that creditors with equal debt-collection skills would accept an insolvency system in which they were paid back equally on their debts, then it has no relevance in analysing those far more numerous situations where there is a great disparity in such skills among creditors. Further, there could then be no claim that the model justifies the coercive collective regime, since it would have failed to demonstrate that nonhomogenous creditors would have given (counterfactual) consent to that regime.

Jackson does struggle with the problem. He tentatively proposes that the assumption of creditor homogeneity 'may not matter to the actual conclusion'. ${ }^{37}$ This would be because, first, participation in the race for the insolvent's assets under the 'grab rule' would be expensive for all creditors, and the collective regime would be attractive to them all as a way of making that expense unnecessary. And second, each creditor might still prefer the relative certainty of ranking pari passu in the collective system over the unpredictability of the grab rule. ${ }^{38}$ However, these reasons are unpersuasive, and fail to take account of the differences in the abilities of various types of creditor. Creditors who are repeat players (like C Ltd. in our example above) and who extend numerous loans over some period of time, enjoy economies of scale in keeping informed of the financial state of their debtors, and in dealing with the consequences of bad loans. So the average cost per loan for them to participate in the race for the insolvent's assets is lower than it is for one-off transactors. Repeat players can also balance the risk of ranking somewhat lower in some transactions with the possibility of ranking somewhat higher in others. This might make the aggregate risk of their portfolio of loans fairly predictable. Again, one-off lenders would not have this ability to diversify. These arguments should reinforce the conclusion reached above, that different creditors would make different demands at the ex ante stage, and only some types of creditor would find the automatic stay to be in their interest.

\section{FAIRNESS IN THE CREDITORS' BARGAIN}

We have already seen three problems with the ex ante position of the Bargain model. First, it is based on mere preferences, and seems to provide no reason why some preferences should be more binding than others. Second, the model is arbitrary, and does not explain which of numerous possible ex ante positions -- each leading to a different conclusion -- is the correct one. And third, the ex ante position has been defined -- knowingly and deliberately -- using the Real Parties in Natural Ignorance conditions. Since the parties are aware of what makes them different at the time that the bargain is supposed to be concluded, no agreement would be reached on the automatic stay.

Can it be argued that the model actually stipulates there is no exit option, in other words, that agreement must be reached? It might be said that there is obviously a system of rules and principles designed to govern the claims of creditors in their debtor's insolvency.

\footnotetext{
35 'Entitlements', pp 863-4; see also Bankruptcy, p 15.

36 Ibid.

37 Bankruptcy, p 15 fn 18.

38 Ibid.
} 
So the question to be put to the model is not whether such a system would exist, but what sort of system it would be. However, this objection would overlook Jackson's observation that the bargain is to be concluded by those aware that 'a system of [non-insolvency] law entitlements is already in place' and also 'what their priority position will be so long as [non-insolvency] law continues to govern their rights. ${ }^{39}$ So the creditors' inability to agree to the automatic stay would lead, not to paralysis, but to the continuation of the pre-insolvency individualistic debt-collection system. If there were no exit option in the model, the model would not predict there was no method at all for dealing with situations where the debtor defaults on multiple debt obligations. The method it did predict, though, would not be the one we have.

Still, supposing an agreement were to be reached by the creditors ex ante, what sort of agreement would it be? Recall again that the bargain is to be concluded by Real Parties, who are as different from each other as creditors are in real life. At the time the negotiations take place, they are aware of whether they are unskilled employees who might become creditors in their employer's insolvency, or commercial banks, or directors who will also lend to their company, etc. Now in the bargaining, and motivated by nothing but self-interest, all the creditors would seek to preserve as many of their pre-insolvency relative advantages as possible, and to dilute the relative advantages of others as much as possible. Creditors would make proposals as to the type of insolvency regime to be chosen with this aim in mind. Since there would have to be an agreement, some give and take would be essential. This would presumably involve giving up some of one's pre-insolvency advantages in return for others doing the same. But it follows that those with little pre-insolvency clout would have little to offer in the negotiations, and therefore little bargaining strength. The weakest creditors -unskilled employees or those whose contributions could be regarded as fungible, trade creditors in a competitive industry, etc. -- might find their interests almost completely unprotected by the rules eventually chosen. ${ }^{40}$

It should be obvious an agreement reached under these circumstances would have little normative appeal. The model allows those strong in real life to bring their advantages to the bargaining table. By the same stroke, it compels the weak to be burdened by real-life disadvantages in the negotiations. The resulting rules are shaped so as to allow the very strong completely to overwhelm the very weak. But these rules are not just rules. Just rules must be laid down precisely because individuals in real-life are strong, weak, or helpless, and because it is not fair to allow the strong to overwhelm and exploit the weak. Justice redresses bargaining advantages, but the Creditors' Bargain merely reflects them. The model therefore generates no normative appeal for the rules it predicts the parties would have chosen. Recall also the note of caution struck at the beginning of Section 4(b) above. We can now reasonably conclude that since the ex ante position is arbitrary, and since it has no normative appeal, any suggestion that it confers some privilege even on mere preferences expressed then, should be rejected.

\footnotetext{
39 Jackson and Scott 'Nature', p 499. Note yet again this crystal-clear endorsement of Natural Ignorance.

${ }^{40}$ This paragraph draws on Gauthier Morals by Agreement (Oxford: Clarendon, 1986), Ch. 5. It develops Gauthier's insight that in a bargain between rational self-interested parties, Party X may not claim any part of the pay-off enjoyed by Party $\mathrm{Y}$ in the 'initial bargaining position' (which here is the non-insolvency debt-collection system), but only some part of the 'co-operative surplus'. So for example, bank-creditors would attempt to retain at least as much as they could get for themselves without a collective system. If they could not, they would still wish to minimise the amount they would have to give up. (On this last point, the position taken here departs from Gauthier's, since here we imagine a bargain even though there is no co-operative surplus from the bank's perspective.)
} 


\section{PRELIMINARY CONCLUSIONS AND A NEW START}

It has been argued the Creditors' Bargain has neither descriptive nor moral force. It fails on the first count because it relies on a confused and ultimately meaningless notion of consent. It suggests that driven by self-interest, all creditors would accept the automatic stay on unsecured claims in their debtor's insolvency, if only they could be consulted before lending anything. But the interests of the creditors are a function of the time at which they are calculated, and of what is then known about the world. The Bargain model specifies no nonarbitrary point at which this calculation could be made and as a result is quite indeterminate. Further, it relies on nothing but creditors' preferences, and suggests no reason why those preferences ought to be considered binding. Creditors actually asked ex ante to choose an insolvency regime would either be unable to reach agreement, or would pick a system designed to reflect their pre-insolvency advantages. In any case, any agreement made under the circumstances of the Bargain model would likely be exploitative and oppressive of weaker parties, and would have no justificatory force.

Recall from the first Section above that the automatic stay on unsecured claims is the most distinctive and well-established part of all of insolvency law. Since the Bargain model can not even predict (and therefore can not explain or justify) the collective regime defined by the stay, it can have little use in analysing any of insolvency law. But despite the fact that Jackson is ultimately unsuccessful in explaining the automatic stay, there are valuable lessons to be learnt from his failure. The insights gained from examining - and rejecting - the Bargain model are useful in any attempt to do better. The remainder of this article is a modest start in that direction.

It is suggested that insolvency law, and in particular the automatic stay on unsecured claims, can be justified by asking what all the parties concerned would agree to, if given the chance to bargain under suitable conditions. The consent relied on here is again hypothetical consent. Here, though, the consent is not of 'real world parties', nor are the parties allowed to deploy 'actual endowments of skill and energy' in the bargaining process, nor are they in Natural Ignorance. Rather, hypothetical consent is given by all the relevant parties, conceived of as free, equal, and reasonable, under conditions which will be referred to as Dramatic Ignorance. As such, this model is based on 'authentic consent', the consent of the 'true and genuine person'. ${ }^{41}$

So the model developed here is again contractarian. Specifically, it is Rawlsian, and draws on notions famously elaborated by John Rawls in A Theory of Justice, ${ }^{42}$ and restated and modified in Political Liberalism. ${ }^{43}$ It was noted above that Jackson also claims his Creditors' Bargain is an application of Rawls' methodology. But it will become apparent as the argument progresses that 'It is hard to exaggerate the difference between these two versions of contractarianism. ${ }^{44}$ The Creditors' Bargain is a 'mutual advantage theory'. The Authentic Consent Model (ACM) is based on 'justice as reciprocity'. This is discussed below. Note also that this article is not the first manifestation of the desire to counter Jackson's attempt wrongly to claim Rawls as his own. Donald Korobkin constructed a selfconsciously Rawlsian alternative to the Creditors' Bargain in $1993 .{ }^{45}$ The present work sets off in the same direction, and follows a similar route. But while the impulse which drives

\footnotetext{
41 Dworkin 'Efficiency', p 575, who warns the term 'authentic consent' can be 'misleading'.

42 Cambridge, Mass: Harvard Univ. Press, 1971 (hereafter 'Theory').

43 New York: Columbia Univ. Press, 1996 (hereafter, following Rawls' own preferred abbreviation ' $P L$ '; see $P L, \mathrm{p}$ xxxvii).

${ }_{44}$ Kymlicka, Contemporary Political Philosophy (Oxford: Clarendon, 1990), p 128, contrasting Rawls' approach with 'mutual advantage' theories.

45 'Contractarianism and the normative foundations of bankruptcy law' (1993) 71 Texas LR 541.
} 
both Korobkin's essay and this article is the same, the two encapsulate radically disparate visions of the role of insolvency law, and reach very different results. The points of disagreement will become apparent very shortly.

\section{THE PLOT}

This model regards corporate insolvency law as dealing with that peculiar set of social, commercial, and legal circumstances which arise when a company becomes insolvent. Insolvency law is seen as laying down the fair terms of co-operation among all the parties affected by these peculiar circumstances. The parties themselves are considered free and equal, and as fully co-operating members of society. In this model, insolvency law is one limb of the whole legal corpus, and (like the legal system in its entirety) provides the guidelines for how the institutions within its province are to realise the values of liberty and equality. The model specifies a point of view from which these principles can be seen as more appropriate than any others to the idea of the parties conceived in this way (this is the model's choice position) ${ }^{46}$ The following Sections consider the model's conception of the person, and the point of view from which the principles to be proposed in this model are to be judged. Here, the province of insolvency law is mapped out, and the idea of social cooperation is discussed. It will be seen that elements discussed in this Section surface again in different guises in subsequent Sections, reinforcing and illuminating what has gone before. This pattern will recur throughout the rest of this article.

\section{a. The province of insolvency law}

One could perhaps be forgiven the assumption that to assert that corporate insolvency law should be seen as dealing with issues peculiar to corporate insolvency, is to assert something trivial and banal. And yet this is one of the more controversial issues in insolvency scholarship. A great virtue of the work of the proponents of the Creditors' Bargain is its clearer appreciation of the nature of insolvency law and its limits, and of the boundaries between insolvency and non-insolvency issues. Other commentators have found these distinctions either too fine to notice, or inconvenient enough to ignore. They seem to see insolvency law as the panacea for most of what they regard as wrong with society. Whether it be the under-representation of employees in corporate decision-making, the supposed insensitivity of boards of directors to broad social concerns, or the tendency of capitalist competition often to expose people to hardship, the solution is argued to lie in amending insolvency law in particular ways, and applying it in a certain manner. However, it is argued here that such an approach undermines what must be a fundamental goal of every reasonable legal system: that like cases be treated alike. The fact is that the ambit of corporate insolvency law is necessarily limited. To overlook this in selecting principles of insolvency law would be to ensure the law as a whole treated similarly-placed individuals differently for wholly arbitrary reasons.

Take Korobkin, who advocates a view of insolvency law defective precisely for this reason. He regards insolvency law as a response 'to the problem of financial distress'. ${ }^{47} \mathrm{He}$ argues that a corporation, like a household, is a focal point of social interaction for mutual advantage. 'In diverse ways, persons invest in the corporation and, in turn, become

\footnotetext{
${ }^{46} P L$, Lecture 1; see esp pp 3-5.

47 Korobkin 'Foundations', p 546.
} 
"invested" in it as a source of financial and personal fulfilment. ${ }^{48}$ Such investments are not made only by shareholders, creditors, employees and directors, but also by the company's 'customers, the friends or family of those who work for the corporation, and the citizens of communities directly affected by its operation. ${ }^{49}$ In fact, 'the problem of financial distress affects virtually all persons in society to some degree'. ${ }^{50}$ When struck down by financial distress, the corporation -- this pivotal, almost organic social institution with its widespread and deep-rooted ties with everyone in society -- suffers 'a crisis in "collective autonomy"... [losing] the capacity to regulate itself according to collectively chosen, mutually constructive ends. ${ }^{51}$ All the economic, personal, and social ties constructed around its existence are suddenly in jeopardy.

Insolvency law must be seen as a response to these circumstances, addressing the 'failure of collective autonomy' and 'supplying the reflective capacity that the enterprise [now] lacks. ${ }^{52}$ Insolvency law is not merely (or even primarily) a more efficient collective debt-enforcement mechanism. It must do much more. It must 'address the concerns of the employee who fears the loss of employment', for example. ${ }^{53}$ It must pay heed to the plight of 'an employee who [entered] the corporation without skills or training and is thus viewed by her supervisors as especially dispensable. ${ }^{54}$ It must even seek to provide representation at some level to 'affected members of the community at large' and their 'diverse political, moral, and personal values. ${ }^{55}$ And if, in achieving these aims, insolvency law must violate the pre-insolvency rights of those with direct financial concerns in the company, then so be it. $^{56}$ With the whole edifice of society seemingly teetering on the brink, and with so many interests to protect and ideals to serve, who would object to the Chancery judge carrying out some redistribution of wealth from the company's creditors, to other groups in society? ${ }^{97}$

It is suggested this expansive benevolence is arbitrary and misguided. Korobkin's grand, imperialistic vision of insolvency law results from a rather simple error. Somewhere along the way, he stops asking himself: What makes insolvency law special?

Consider Companies A, B, C, and D. A, B, and D each operates a manufacturing plant in an identical small community. C operates two such plants in two such communities. Each of these plants is the main employer in the area, the main focus for beneficial social interaction of the sort described by Korobkin. Imagine these small communities having a similar, relatively high rate of unemployment, so that workers in these plants are likely also to be supporting out-of-work family members. Numerous small traders are dependent on each plant, supplying raw material, selling food to the plant's employees, transporting the plant's product and clearing its waste. Suppose also that each community is governed by the same legal system, which is identical to that in England, except in one respect. Insolvency law in this jurisdiction incorporates and reflects all of Korobkin's concerns in a way recommended in his essay.

\footnotetext{
48 Ibid.

49 Ibid.

50 Ibid, p 554.

${ }^{51}$ Ibid, p 548.

52 Ibid, p 548.

53 Ibid, p 555.

54 Ibid, p 558.

55 Ibid, p 570.

56 Ibid, pp 550-1.

57 This observation mirrors Baird 'A world without bankruptcy' (1987) 50 Law and Contemporary Problems 173, 185: 'Requiring those with rights against a firm's assets to take account of the interests of the workers is tantamount to giving the workers rights to the firm's assets.'
} 
Imagine now that there is a similar serious downturn in the industries in which A, B, and $\mathrm{C}$ operate. All three companies (along with thousands of others) are beset by financial distress. A Ltd. is hit particularly hard, and being the worst prepared, is forced into insolvent liquidation. C Ltd. responds by deciding to focus on its core competence. It sells off one of its plants to E Ltd., and concentrates on the other. Both business units recover and become profitable. B Ltd. meets the challenge by rationalising its operations and downsizing. Dozens of employees 'who [entered] the corporation without skills or training and [are] thus viewed by [their] supervisors as especially dispensable' are fired. B too survives the crisis. D Ltd. has not been affected by financial distress at all. It was set up by X fifty years ago, who has run it since as a friendly, only semi-professional enterprise, not worrying too much about turning a big profit. At around the time $\mathrm{A}, \mathrm{B}$, and $\mathrm{C}$ are going through the pangs of financial distress, $\mathrm{X}$ dies. $\mathrm{X}$ has no family, and no buyer can be found for the factory, so it is boarded up. The heart is ripped out of the community. People lose their jobs, and other businesses in the community dependent on $\mathrm{D}$ become insolvent.

The purpose of sketching out this scenario at some length is to show that Korobkin's analytical chain, made up of financial distress, corporate insolvency, and undesirable social costs, breaks down at each of its links. A Ltd. initiates a formal insolvency proceeding, and those associated with it enjoy the (dubious) benefits of Korobkin's luxurious insolvency regime. Arguably, they do not lose their jobs and social interaction, and are given the opportunity to reconcile their diverse social, political and personal values, while A Ltd.'s creditors are bled dry. ${ }^{58}$ The problem is that the provisions of Korobkin's insolvency regime apply only to insolvent companies, that is, those unable to pay their debts as they become due, or whose liabilities exceed their assets. ${ }^{59}$ But what about B Ltd.? It suffers financial distress but never becomes insolvent, and so those associated with it never get the protection of Korobkin's insolvency regime. Yet its most vulnerable employees suffer the ravages Korobkin must think are exclusive to insolvency situations. If Korobkin does not think so, then why does he discriminate between A's and B's workers? Why under his regime are the former 'better off' than the latter, when the two groups are subject in exactly the same way to their employers' financial distress? Similarly, the communities woven around A Ltd. and D Ltd. are threatened in exactly the same way, even though $\mathrm{D}$ is not the victim of financial distress. Since D never becomes subject to insolvency law, it never enjoys the benefits of Korobkin's vision. Korobkin wants to give the community in which A operates additional rights, but seems unmoved by the identical plight of D's community. His model creates a discrepancy in the treatment of people who are going through exactly the same problems. Again, Korobkin must believe the community affected by A's insolvency is more worthy of protection than that devastated by D's closure, but he provides no reason for taking that position.

The point is simply this. Korobkin pursues goals through insolvency law which -- if considered desirable -- ought to be pursued by the general (non-insolvency) law. If workers deserve protection against dismissal even though they are judged superfluous to their

\footnotetext{
58 This, at least on one very plausible view, is partly what happens in proceedings governed by Chapter 11 of the US Bankruptcy Code, which Korobkin supports both in the article under discussion and elsewhere.

${ }_{59}$ IA, s 123. It is very important to note that in fact, this argument is broader: B, C and D never invoke any special procedure designed to deal with companies in 'financial distress', and remain subject only to general company, employment, and social security laws etc. So this argument applies with equal force to any Korobkinian changes either to liquidation or to so-called 'rescue' regimes (the latter may only be available in a firm's insolvency; alternatively, they might be open to invocation without the need to demonstrate insolvency). The real contrast is between 'ordinary' law which deals with companies throughout their existence, and special provisions which may be invoked only when a firm is in crisis.
} 
employer's plans, then this policy should be implemented generally, not merely restricted to that minority of workers whose employer becomes subject to insolvency law. ${ }^{60}$ If people who have not made direct financial contribution to the firm ought still to be given the right to decide what happens to the firm's assets, then this right should again be conferred on all similarly-placed parties. To create these rights only when the firm becomes subject to a formal insolvency proceeding is to make arbitrary distinctions. Korobkin claims his model produces principles which are 'fair', which have 'real normative force'. ${ }^{61}$ Unconstrained arbitrariness of the sort found in his model is not a hallmark of fairness, nor does it commend itself as a normative principle. ${ }^{62}$

It might be urged in response that 'there is no reason why issues arising in insolvency should be governed by rules or agreements formulated without regard to insolvency'. ${ }^{63}$ But with respect, while the sentiment thus expressed is sound, ${ }^{64}$ its invocation here would miss the point completely. Simply because an issue can 'arise in insolvency' does not by itself mean it should be dealt with by insolvency law. Consider an analogy. That a murder has taken place in a vehicle on a public highway rather than in a house (say) should not make a difference to the law which applies to the situation. This despite the fact that the 'issue has arisen' against the background of the regulation of traffic on the roads, and that the law of murder is 'formulated without regard' to that background. Similarly, the issues of workers losing their jobs, of communities being devastated when businesses close down, of tax authorities losing revenue, all can and do arise without the company in question ever becoming subject to insolvency law. Exactly the same issues exist whether or not the relevant legal entity is able to pay off all its debts. ${ }^{65}$ Insolvency is here an irrelevant part of the factual background, analogous to the number of times the letter ' $a$ ' occurs in the name of the

${ }^{60}$ Anyone suggesting special protection for displaced employees of insolvent businesses would have to face the fact that twelve times as many businesses close down without defaulting on their debt obligations (and therefore without invoking any formal insolvency procedure) as those which do become unable to pay multiple debts; see Bank of England, Finance for Small Firms: A Sixth Report (January 1999), p. 22 including fn. 24, citing Storey, "Firm size and performance", in Acs and Audretsch (eds.), The Economics of Small Firms (Kluwer, London, 1990). So proposals of the sort made by Korobkin, which are meant to protect (say) employees but which apply only to employees of insolvent businesses, would leave upto $90 \%$ of their target population unprotected. This objection holds for all the other groups Korobkin wishes to 'protect'.

${ }^{61}$ Korobkin 'Foundations', p 571.

62 This discussion should dispose of arguments similar to Korobkin's, made by Warren 'Bankruptcy policy' (1987) 54 Univ. Chicago LR 775 (argues that the role of insolvency law is to (re-)distribute losses associated with business failure; however, the sort of losses Warren is concerned with can and do accrue to the same types of parties without their becoming subject to insolvency law at all), and Gross, Failure and Forgiveness: Rebalancing the Bankruptcy System (New Haven: Yale Univ. Press, 1997) (argues that insolvency law must protect 'community interests'; again, though, such community interests can be and are threatened in an identical way without insolvency law being implicated). A similar argument is mentioned by Finch 'The measures of insolvency law' (1997) 17 OJLS 227, 234: '[I]nsolvency [law] does and should recognize the interests of parties who lack formal legal rights in the pre-insolvency scenario not least because parties with formal legal rights never bear the complete costs of a business failure' [footnote omitted]. Again, Finch fails to recognise that such 'costs' can fall on parties without legal rights even when the business in question shuts down without ever becoming subject to insolvency law. To avoid arbitrariness, Finch (and Warren and Gross) should be making such an argument in the context of general company law (or indeed that of employment or social security law).

${ }^{63}$ Finch 'Measures', p 237. Finch attributes this 'response' (and the one discussed next) to 'communitarians'. Since she does not name particular communitarians willing to own up to these views, it might reasonably be assumed she is making a 'communitarian' argument herself.

${ }^{64}$ See Mokal 'Priority as Pathology'.

${ }^{65}$ It should be obvious the argument here is not meant to apply to the plight of any of these parties qua creditors. 
insolvent's managing director. The law as a whole should not make distinctions based on the former any more than it does the latter.

It might also be argued that 'it is perfectly proper to advert to [concerns about the protection of jobs, communities, etc.] in both pre-insolvency and insolvency law. ${ }^{66}$ With respect, this again misses the point. If the law deals with identical issues in the same way regardless of whether the company in question is insolvent (as it should), then insolvency law is not playing any role at all. ${ }^{67}$ The fact that the vehicles owned by a company must obey traffic rules regardless of whether the company is in the process of being liquidated, does not make the traffic code part of insolvency law when it is applied to vehicles in fact owned by insolvent companies! One would have thought the point was a simple one. To classify a part of the law as the road traffic code is to classify it functionally, that is, on the basis that it deals with issues specifically associated with the regulation of traffic on the roads. Similarly, to classify another part of the law as insolvency law is to classify it on the functional basis that it deals with issues specifically associated with corporate insolvency. The desire on part of some insolvency law scholars to claim for their subject the greatest jurisdiction they can might be understandable, but it is also pointless and ultimately (because of the potential for arbitrariness) harmful.

The ACM developed here focuses, then, on what makes insolvency law special. It provides and validates principles to govern insolvency issues. It accepts that not all insolvent firms will come to be governed by those principles, since not all such firms would invoke a formal insolvency proceeding or otherwise become subject to insolvency law. No part of the law has full control over its province. Not all crimes are punished, nor all torts compensated, nor all breaches of contract remedied. So this model makes no claims to omnicompetence on behalf of insolvency law. At the same time, it provides a standpoint from which to judge any proposal suggested as a candidate for an insolvency law principle. Any proposal which passes the tests set by this model can be regarded as just, and as an appropriate principle of that law.

\section{b. Co-operation in insolvency situations}

Within the constraints mentioned above, and with respect to the issues regarded as peculiar to corporate insolvency, insolvency law lays down the terms of fair co-operation. Now the commercial world is characterised by competition and often, conflict. In the circumstances of a firm's insolvency, some claimants (to take its defining characteristic) do not get back all (or any) of what they are owed. Conflict seems almost to be built into the nature of things. It might seem unrealistic to posit co-operation to the parties playing this (apparently) zero-sum game. So it is essential to be clear about the nature of the co-operation which the ACM sees as being at the core of insolvency law.

All the parties facing a set of peculiar insolvency issues co-operate by accepting, regarding as proper, and being guided by certain public rules and procedures. Co-operation takes place on terms 'each participant may reasonably accept, provided that everyone else likewise accepts them. ${ }^{68}$ Each party which complies with the publicly recognised rules is to benefit in an appropriate way, usually by being allowed to advance its own conception of the good in those circumstances. As conceived here, then, parties governed by insolvency law who are in a position of potential conflict inter se, nevertheless co-operate by each being

\footnotetext{
${ }^{66}$ Finch 'Measures', p 237 (emphasis in the original).

67 And of course if the issues are not identical and one arises only in insolvency, then we would not be violating the prescription that insolvency law should only deal with issues peculiar to insolvency.

${ }^{68} P L, \mathrm{p} 16$.
} 
guided by just insolvency law principles in pursuing their own self-interest, and thereby allowing all others similarly to pursue their self-interest guided by the same principles.

Note that reciprocity of this sort is key. Each party is motivated to seek their selfinterest only in accordance with insolvency law principles regarded as just by the ACM, because they consider it fair to do so, but only if (most) others are also seen to accept as fair and abide by the same set of principles. If one of the participants in the institutions of insolvency law asks why he should abide by the principles on which the institutions operate, he can be told:

You have the opportunity to pursue your self-interest only because others constrain themselves in ways that make for a fair cooperative venture for mutual advantage. Constrain yourself by those same principles in return, and you give them fair return for what they give you. ${ }^{69}$

Now there is no doubt that 'reciprocity is a form of fairness'. ${ }^{70}$ But it has been subject to some criticism as the basis for a just political order. (Insolvency law of course would be part of such an order.) It has been noted that those incapable of providing reciprocal benefits are excluded from any conception of justice based on reciprocity. ${ }^{71}$ Even when, as in the ACM, the 'benefit' parties must provide to each other is to accept as fair, and abide by, the same set of principles as everyone else similarly placed, some are excluded. These would include the congenitally handicapped of some variety, and animals, both incapable of upholding any principles. ${ }^{72}$ For those who 'hope[] for a conception of justice that admits these cases as central', reciprocity is unsatisfactory. ${ }^{73}$

There are a number of ways of responding to this criticism. The most obvious is to point out that in the specific context of corporate insolvency, it has little relevance. Here, even the weakest party -- the literature mentions the tort victim, the unskilled employeecreditor and the weak trade creditor as paradigms -- is capable of reciprocating by suspending their efforts individually to pursue whatever claims they have against the insolvent, and by regulating their activities in accordance with fair insolvency principles.

Even on a more general, society-wide level, the criticism that reciprocity would exclude those incapable of reciprocating from the realm of justice, still seems irrelevant. Claims on behalf of groups such as the congenitally disabled, and animals, have often been phrased in terms of justice. But justice is not the only social or political virtue. Not every instance of social, or even political, interaction need be governed by it. There are other virtues, like mercy, benevolence, empathy, altruism, charity, etc. A society might accept any of these as political virtues. Claims on behalf of animals might still be phrased in terms of the obligations of human beings, for example, but these obligations would flow from empathy (say) and not justice. The desire of those campaigning on behalf of such groups to cover their claims with the cloak of justice can be attributed either to their inability to identify other political virtues, or their suspicion that society generally does not recognise virtues other than justice. But such inability or suspicion is based on an impoverished view of political discourse, and its manifestations serve merely to confuse that discourse.

\footnotetext{
${ }^{69}$ This paraphrases in Gibbard 'Constructing justice' (1991) 3 Philosophy and Public Affairs 264, 269.

70 Barry, Justice as Impartiality (Oxford: Clarendon, 1995), p 50; the significance is that Barry is one of the leading critics of 'justice as reciprocity' theories.

${ }^{71}$ Ibid, p 50 .

${ }^{72}$ Ibid. See also Kymlicka, Philosophy, p 129.

${ }^{73}$ Gibbard 'Justice', p 272.
} 
We can move on, then, keeping in mind what motivates the ACM. Within the terms of the model, insolvency law is seen as a fair system of co-operation about insolvency issues. All those participating in its institutions are motivated by the desire to further their selfinterest bound by a set of fair principles, and in the knowledge that everyone else is similarly bound.

\section{THE CAST}

It has been mentioned that the ACM is contractarian, based on the hypothetical consent of the relevant parties. This Section sets out the criterion by which parties are to be admitted to the choice position, and therefore to be allowed to give their consent to -- or to withhold it from - any proposed principle. ${ }^{74}$ It should be noted that the aim of this article is (inter alia) to provide the broad test which can identify these parties. It sets out and defends the principles which (it is contended) ought to be applied to determine whether a particular party should be given a say in the selection of fair insolvency law norms. The article does not itself seek to make a comprehensive identification of all such individuals (or indeed groups).

The ACM is based on the fundamental idea that:

it is fair to require people to submit to procedures and institutions only if, given the opportunity, they could in some sense have agreed in advance on principles to which they must submit. ${ }^{75}$

People must be consulted on the choice of governing principles because they would later have to submit to those principles. The only reason why their participation must be sought in the bargaining process is because their rights, interests, and obligations will be affected by these principles. But this means those who do not have to submit to those principles should have no say in their selection. Suppose a set of principles does not affect the rights, interests, or obligations of $\mathrm{X}$ at all. In that situation, it is difficult to see why $\mathrm{X}$ ought to be consulted on how $\mathrm{W}, \mathrm{Y}$ and $\mathrm{Z}$-- all of whom are affected by that set of principles -- should be expected to behave. In the ACM, insolvency law is regarded as dealing only with insolvency issues. It follows that only parties affected by insolvency issues are to be allowed a say in the choice of principles to govern such situations. ${ }^{76}$ Crucially, though, note that the question "who is affected by insolvency issues?' is to be answered broadly. There is no restriction, for example, that only those with direct financial concerns in the insolvent company are to be taken as affected by corporate insolvency. This should make it clear the ACM rejects the narrow concerns of the Creditors' Bargain, which restricts participation in the ex ante agreement to those who have contracted for legal rights to the debtor's assets once insolvency has occurred. ${ }^{77}$ So shareholders are not included in Jackson' model, ${ }^{78}$ nor on one view are non-consensual creditors like the debtor's tort victims. ${ }^{79}$

\footnotetext{
74 This is subject to the parties' being equal. The next two Sections explain the concept of equality, which is the necessary condition for admission to the choice position. That and the criterion discussed here together constitute the sufficient conditions for admission.

${ }^{75}$ Nagel 'Rawls on justice', in Daniels (ed.), Reading Rawls: Critical Studies on Rawls' 'A Theory of Justice' (Stanford: Stanford Univ. Press, 1989), 1, at p 4.

76 See also Finch 'Measures', pp 238-9. The position of those who are not faced with peculiar insolvency issues, but who are affected nevertheless by insolvency law, is dealt with in Section 11(b) below.

77 Jackson Bankruptcy, pp 32-3; Jackson and Scott 'On the nature of bankruptcy: An essay on bankruptcy sharing and the Creditors’ Bargain' (1989) 75 Virginia LR 155, 160-2, but see pp 194-6.

${ }^{78}$ Jackson 'Bankruptcy', p 868 fn 52.

79 Jackson and Scott 'Nature', p 177.
} 
The ACM welcomes any proposal that a certain principle be admitted into insolvency law, and judges that proposal by asking the central question: What makes insolvency law special? Any party -- no matter how remote it might prima facie seem to be from insolvency issues -- can argue that its interests are affected by those issues in a way special to corporate insolvency. There might be issues peculiar to insolvency situations which affect parties other than creditors. Insolvency law must have principles to govern such issues when they arise, and in selecting those principles, all those affected must be given a say. To take just one example, the wrongful trading provisions of the Insolvency Act $1986^{80}$ lay down principles dealing with a manifestation of the old agency problem in the peculiar circumstances of corporate insolvency. The provisions affect the rights, interests, and obligations of managers and shareholders, as well as creditors. In deciding whether the wrongful trading provisions can be justified, the ACM therefore allows participation to shareholders and managers, as well as creditors. ${ }^{81}$

So the model extends participation to parties other than creditors because it focuses on what makes insolvency law special. For the same reason, it rejects exorbitant claims of the sort exemplified by Korobkin:

[The] problem of financial distress affects virtually all persons in society... As a result, all persons in society should have representation in the choice of [insolvency law] principles' ${ }^{82}$

As already argued, issues related to financial distress which are not peculiar to corporate insolvency are to be settled so as to prevent the creation of arbitrary distinctions between those faced with exactly the same circumstances, based on whether they become subject to insolvency law. If employees, members of the broader community, or their friends and family are affected by financial distress in a way that they would be whether or not the debtor becomes insolvent, then the choice of principles governing their circumstances must be made in models justifying employment, general company, or social security law. As conceived of here, insolvency law is not hegemonistic, nor does it exhaust opportunities for doing good. ${ }^{83}$

\section{THE CHARACTERS}

It was argued in the first part of this article that actual parties in real-life transactions have varying bargaining power, negotiating skills, cognitive abilities, financial muscle, and clout

\footnotetext{
80 Section 214.

81 Mokal 'Wrongful trading' analyses these issues using a method which can be regarded as lying halfway between the Creditors' Bargain and the ACM. All its material conclusions would remain unaltered if put to the test within the framework being laid out here.

${ }^{82}$ Korobkin 'Foundations', p 554.

${ }^{83}$ Incidentally, this also counters criticism of the sort levelled against Korobkin by Finch 'Measures', $p$ 235 , that 'principles of insolvency law designed by a veiled and highly inclusive group are liable to be so protective of so many interests, and as a result so uncertain, that the effects on the cost of credit would be catastrophic.' The ACM certainly does not face this problem. Those invited to participate in the choice position here are all parties affected by corporate insolvency in a unique way. The interests to be protected are interests either threatened only in the debtor's insolvency, or threatened by it in a manner peculiar to insolvency. The categories of such interests are unlikely to be wide. In fact, Finch's criticism is unfair even to Korobkin, who himself seems to recognise his approach is hopelessly wide and attempts to respond. After framing what is supposedly the foundational principle of his model, the so-called 'principle of inclusion' which opens the door to 'virtually all persons in society', he goes on effectively to deny this principle any significance at all; see 'Foundations', pp 574-5, esp fn 162, p 581, etc.
} 
with the debtor. These are the 'real world parties' of the Creditors' Bargain, and while such real-life transactions might be fair against the background of just principles, the selection of the principles themselves can not be allowed to reflect these differences. ${ }^{84}$ Principles formulated merely to reflect such differences, and not concerned with protecting the weak against exploitation resulting from the differences, would not be just. The ACM claims to be able to pronounce on the justice of insolvency law principles. It can not therefore be based on the consent of Real Parties.

So this Section starts the process which will transform the actual people who will eventually find themselves governed by insolvency law principles -- the cast -- into parties capable of giving authentic consent to those principles -- the characters. This process will not be completed until the next Section. ${ }^{85}$ This Section explains the way in which the relevant parties are to be considered free and equal. They are also to be considered reasonable, and this will also be explained. Finally, the role of self-interest in the ACM is described.

The key tool here is the notion of a constructive attribute. ${ }^{86}$ Constructive attributes are stipulated features of the ACM, to be imputed to the parties in order for them to be able to give authentic consent. In order to construct the relevant attributes, the ACM surveys the whole legal and political culture of society. It gathers together all the data which seems relevant. This might include any of legislative enactments and judicial precedents, administrative and executive acts of government, the binding commitments of the State in the realm of public international law, pronouncements of leaders of opinion in society, and so on. ${ }^{87}$ The model then analyses this raw material and distils it to its essentials. The quest is to define 'the political conception of the person' ${ }^{88}$ It is to define a certain ideal of the individual: the ideal of the citizen as legislator in a democratic society. ${ }^{89}$ Whatever characteristics seem relevant to this ideal are then attributed to the parties who will negotiate in the hypothetical bargain to decide on insolvency law principles.

Note that the ACM does not presuppose any metaphysical doctrine of the person, realist, idealist, or materialist. ${ }^{90}$ Nor does it assume the characteristics constructively to be attributed to the parties really do exist in all (or most) actual individuals. ${ }^{91}$ Constructive attributes constitute an ideal of the person. They define a normative view of how parties must be placed before being asked to give consent to principles of justice. To the extent that reallife individuals lack these attributes, they fall short of what society expects of its legislators. So to insist that (some) actual people are not free or equal or reasonable in the sense defined below is to point out a deficiency in actual society, not in the model. Constructive attributes define a contingent view of the person, based firmly in the political and legal culture of society and answering to its highest conceptions. The model claims a particular society accepts it should be governed by principles which could be regarded as acceptable to citizens

\footnotetext{
${ }^{84}$ A contract between $\mathrm{X}$ and $\mathrm{Y}$ might be fair, even though $\mathrm{X}$ is immensely rich and $\mathrm{Y}$ immensely poor. But a necessary (though perhaps not sufficient) condition for it to be so is that the law giving effect to the contract does not accord certain privileges to $\mathrm{X}$ on account of his wealth which are not given to $\mathrm{Y}$, nor apply disabilities to $\mathrm{Y}$ on account of his poverty which do not apply to $\mathrm{X}$.

${ }^{85}$ Members of the cast are really 'in character' only once on stage.

86 The terminology and the discussion borrow vaguely from Dworkin's exposition of a constructive coherence theory of morality in 'The Original Position' in Daniels, Rawls, 16, at p 27 et al. The idea is developed further, in the context of Dworkin's theory of legal adjudication, in Law's Empire (London: Fontana, 1986). See also Theory, p 18.

87 This list is merely illustrative.

${ }^{88}$ The phrase is Rawls'; see $P L, \mathrm{p} 29$.

89 See Theory, pp 261-5 and 584 for the phrase 'ideal of the person'. See also Scanlon 'Rawls' theory of justice', in Daniels, Rawls, 169, at p 177.

${ }^{90}$ PL, p 29 and fn. 31.

${ }^{91}$ Compare Dworkin 'Position', p 28, describing the 'constructive model'.
} 
thus defined. It then reverses the burden of proof, challenging those who disagree to contest this claim. It is then up to them to show that society does not consider citizens conceived in this way as fit to choose the governing principles of justice. (It is important to emphasise the distinct nature of the assumption about self-interest. Except for its first sentence, the discussion in this paragraph does not apply to that assumption. This is explained below.)

\section{a. Liberty}

The first constructive attribute is that of liberty. ${ }^{92}$ Parties affected by peculiar insolvency issues are to be conceived of as free in three respects. First, they are regarded as 'having the moral power to have a conception of the good', and of pursuing it. They are also 'seen as capable of revising and changing this conception'. ${ }^{93}$ One's conception of the good is one's idea of one's rational advantage. In being free in this sense, the parties are regarded as having the ability to decide what they regard as valuable in the relevant sphere of human life. They can choose what they want to achieve, the attachments they want to form, and the loyalties they wish to owe. ${ }^{94}$ They are also regarded as having the right to be seen as independent of these aims, attachments, and loyalties, and thus having the right to review and revise them, while still retaining their political identity. ${ }^{95}$

In the less abstract but arguably no less profound terms appropriate to the realm of corporate insolvency, this aspect of liberty models the parties' ability to choose to contribute financial capital to a company as secured or unsecured creditors or shareholders, or to contribute human capital as directors or employees. It indicates that involuntary and nonconsensual creditors accept that contingencies of the sort affecting them (though often regrettable) are inevitable in any society, and that they have the capacity to revise their conception of the good to decide what best serves their interests once such contingencies have occurred. This aspect of liberty also models the possibility that the same individual may be a victim of an insolvent's tort and have interests in common with others in a similar position, and simultaneously be a secured creditor (directly or through a corporate entity) of another insolvent with a range of interests appropriate to that status. One of the implications of this aspect of liberty is therefore to counter the insidious tendency of viewing various groups of affected parties as mutually exclusive, and as necessarily having 'incommensurable' aims. ${ }^{96}$

Secondly, parties are free in that they are regarded as 'sources of valid claims'. ${ }^{97}$ While legal persons might be seen -- even in terms of their fundamental identity as citizens -as vehicles for others to attain external goals where natural persons might not, both equally are 'entitled to make claims on [insolvency law] institutions so as to advance their conception of the good'. 98

Finally, parties are free in that they are regarded as 'capable of taking responsibility for their ends'. ${ }^{99}$ Citizens are 'thought to be capable of adjusting their aims and aspirations in

\footnotetext{
92 See $P L$, pp 29-35.

93 Ibid, p 30.

94 Ibid, p 19.

95 Ibid, p 30.

96 See, eg, Korobkin 'Foundations', p 570.

$97 P L, \mathrm{p} 32$. Note the exclusion from the text of the adjective 'self-authenticating', which is used by Rawls as appropriate to natural persons. The label is not appropriate as applied to companies, and this is explained in the text.

98 Ibid.

99 Ibid, p 33.
} 
the light of what they can reasonably expect to provide for.' In particular, liberty entails that the parties 'can adjust their ends so that those ends can be pursued by the means they can reasonably expect to acquire in return for what they can reasonably expect to contribute. ${ }^{100}$

\section{b. Equality}

This is the second constructive attribute the parties affected by the circumstances of corporate insolvency are regarded as having. Recall that insolvency law is thought of as laying down the fair terms of social co-operation in the peculiar circumstances of corporate insolvency. All the parties are equal in that all have a capacity for forming a conception of the good under these circumstances, as noted above. ${ }^{101}$ They also all have the capacity to be moved by considerations of reciprocity. ${ }^{102}$ By virtue of having these capacities, the parties are (constructively) equal. ${ }^{103}$ The crucial consequence is that they "have a right to equal concern and respect in the design and administration of the political institutions that govern them. ${ }^{104}$

Equality is the most important of the parties' constructive attributes. It is because they are regarded as free and reasonable that they are allowed to participate in the choice of principles. Equality is the qualifying condition, then. It is possessed by all those who can give justice, and only such people can contract with others in the ACM. ${ }^{105}$

\section{c. Reasonableness}

Parties are regarded as being 'ready to propose principles and standards as fair terms of cooperation and to abide by them willingly, given the assurance that others will likewise do so'. ${ }^{106}$ That parties have the constructive attribute of being reasonable in this way flows from the idea of them being citizens of a society viewed as a fair system of co-operation. Reasonable individuals are not altruistic, they are 'not moved by the general good as such'. They demand reciprocity from other free and equal citizens, so all can pursue their selfinterest bound by the same set of principles similarly acceptable to all. ${ }^{107}$

\section{d. Self-interest?}

Parties are also motivated by self-interest in proposing, considering, and accepting or rejecting principles of justice to govern insolvency situations. It could be argued that in a certain way, this too is a constructive attribute, something citizens as legislators are expected to have in this society:

In a democratic culture we expect, and indeed want, citizens to care about their basic liberties and opportunities in order to develop and exercise their moral

\footnotetext{
100 PL, pp 33-4.

101 Ibid, p 79.

102 See Section 8(b), supra.

103 PL, p 79.

${ }^{104}$ Dworkin 'Position', p 50.

105 This paraphrases Dworkin, Ibid, p 49.

106 PL, p 49.

107 Ibid, p 50.
} 
powers and to pursue their conceptions of the good. We think they show a lack of self-respect and weakness of character in not doing so. ${ }^{108}$

The ACM takes a more tentative view of the role of self-interest. It is hesitant about elevating this supposed characteristic of the parties to the same normative level as liberty, equality, and reasonableness. In fact, it makes a weaker, more contingent assumption that parties are driven (inter alia) by self-interest. The assumption is not normative at all: the model does not assume citizens ought to be motivated by self-interest. (Note the contrast with the three constructive attributes discussed above.) Rather, the assumption is positive, that citizens are in fact thus motivated. This means that if the actual parties -- to whom the principles chosen using the model are to be applied -- are not self-interested, then the principles will be defective to that extent. ${ }^{109}$

Having said that, a word in defence of the assumption. Suppose the principles chosen using the model thus constructed secure certain rights to certain parties, on the assumption that being self-interested, they would want those rights. Suppose though that the parties turn out not to be self-interested in those respects, or to that extent. It would presumably be a rather simple matter for them to forego the protection or advantages afforded to them by those rights. In any case, it would be simpler than the situation of parties who are in reality motivated by self-interest, and who are trying to claim advantages not afforded to them by principles chosen by a model based on the assumption of their being altruistic. It is better for you to have and to be free to give away, than for you to want but not have. In making the assumption that parties are self-interested, the ACM errs on the side of caution. ${ }^{110}$

\section{THE STAGE}

This Section defines and describes the choice position. It is in this position that parties affected by insolvency circumstances are to debate and consent to the principles which will govern those circumstances. Recall from the first part of this article that while accepting the possibility that institutions might be justified because they serve the antecedent interests of all those subject to their writ, we rejected the Creditors' Bargain because it provided no nonarbitrary point at which calculations of antecedent self-interest could be made. In the ACM, the choice position provides the non-arbitrary, morally privileged standpoint from which parties are to make calculations of antecedent self-interest. The normative attraction of the principles chosen stems from the constructive attributes of those making the choice, and features of the construction of the choice position itself. In this position, parties are rational and Dramatically Ignorant. In order to define the choice position, these constituents of its construction are discussed in turn.

\section{a. Rationality}

Parties in the choice position are required to reason rationally. Think of a person, whether 'an individual or corporate person', who has the ability to select and pursue his own aims and interests. 'The rational applies to how these ends and interests are adopted and affirmed, as

\footnotetext{
108 Ibid, pp 76-7.

109 Barry, Theories of Justice (Univ. California Press, Berkeley, 1989), p 338, in the context of Rawls' assumption in Theory that people in the original position care about the welfare of their descendants.

110 For a similar idea, see the comment by Rawls about liberty and the 'primary goods' (discussed below) in Theory, p 143.
} 
well as to how they are given priority. ${ }^{111}$ In selecting the means with which to attain those objectives, rationality implies the ability to be guided by such principles as: 'to adopt the most effective means to ends'. Rational persons can also weigh up how the final ends they are choosing contribute towards furthering their conception of the good, and how they cohere with each other. ${ }^{112}$

One implication of the requirement that parties in the choice situation be rational should be noted. Transaction cost efficiency springs naturally from this assumption. If $\mathrm{X}$ wants to attain objective $\mathrm{O}$, and can choose between Methods $\mathrm{A}$ and $\mathrm{B}$, both of which ensure he will attain $\mathrm{O}$, then rationality requires him to choose whichever method is cost-effective. If A costs him $£ 100$ and B costs him $£ 110$, then ceteris paribus, he must choose A.

\section{b. Dramatic Ignorance}

The notion of Natural Ignorance and its role in the Creditors' Bargain have been discussed above. Natural Ignorance allows parties to know who they are, what attributes they have, and what they value. It only precludes knowledge of how a particular transaction would turn out for these Real Parties. The problem is that, in any contractarian theory of justice, 'The arbitrariness of the world must be corrected for by adjusting the circumstances of the initial contractual situation. ${ }^{, 113}$ But Jackson's ex ante position happily reflects that arbitrariness. The first part of this article concluded by suggesting that without more, there is no moral force in choices made by naturally ignorant parties.

Contrast that notion of uncertainty with Dramatic Ignorance. The astute reader would have gathered by now the significance of the adjective. Performed drama involves the enactment of an often fictional situation by people playing often fictional characters. But despite being 'made up', good drama involves interaction in recognisable (even if unfamiliar) contexts between characters with recognisable attributes. It speaks to the concerns of its reallife audience, offering insight into familiar everyday reality. Drama is often 'dramatic' in another way. It focuses on and exaggerates certain elements of that reality, perhaps forcing a reassessment of their significance.

The ACM is somewhat similar. Its aim is to analyse and justify the principles of insolvency law. To this end, it identifies peculiar insolvency issues and gathers together all the parties affected by these issues. It then imbues them with the constructive attributes it claims democratic society expects of its citizens as legislators. To revert to the simple drama analogy, the cast are now 'made up' and ready to walk out of the wings onto the stage. Once there, they will solemnly act out the roles allotted to them, choosing the principles of justice governing corporate insolvency. But once on stage, they would also have cast off their personalities and characteristics, assuming instead their dramatic personae. In the terminology employed here, they would be in a state of Dramatic Ignorance.

The ACM requires all insolvency principles to be agreed to by all the relevant parties. But this agreement must not be extracted under conditions of Natural Ignorance. It must be fair, entered into under appropriate circumstances. It must be based on the premise that parties are free and equal, and it must not allow some of them to dominate others because of strength, financial clout, or superior bargaining skill. The first half of this article considered one reason why the existence of such factors, without more, renders an agreement unjust.

\footnotetext{
111 Ibid, p 50.

112 Ibid, pp 50-1.

113 Theory, $\mathrm{p} 141$.
} 
Natural Ignorance does not work because it allows parties knowledge of such attributes during the bargaining, and parties can use these factors to influence the bargaining process. Weaker parties have not therefore been treated fairly in having their interests represented by the rules eventually chosen. But note another, somewhat different reason why Natural Ignorance does not guarantee fairness. It allows parties knowledge of their social position and their conception of the good. In proposing and assessing insolvency principles, parties would favour that position and further that conception of the good. But:

the fact that we occupy a particular social position is not a good reason for us to propose, or to expect others to accept, a conception of justice that favors those in this position. ${ }^{114}$

So the fact that one is a bank or a tort creditor or a director, that one is likely to lend secured or unsecured, is not a good reason for proposing rules of justice favouring that position, or which further the interests typically associated with that position. Rules of justice must be impartial, giving equal weight to the concerns of all groups of claimants.

Note also that insolvency law does not simply affect those actually faced with peculiar insolvency issues. It also has an impact on others who anticipate having to face such issues and plan accordingly. Parties often conduct their dealings with an eye on numerous contingencies, not all of which materialise during the course of their transactions. This is certainly true of insolvency. It is also the case that parties bargain in the shadow of the law. They make plans, demand rights, and accept liabilities, all in anticipation of how they will be treated, should insolvency law affect any part of their dealings. So in selecting principles of insolvency law, the interests of such parties -- i.e. those who must plan their affairs because they might face issues peculiar to insolvency, but who actually turn out not to be thus affected -- must also be protected. To safeguard these interest, parties in Dramatic Ignorance are deprived of knowledge about whether the debtor in question will in fact become insolvent. Since they do not know whether they would actually have to deal with insolvency issues, or merely to make plans to do so without actually having to rely on those plans, the parties would choose principles which pay equal regard to the set of interests associated with each of those affected by insolvency law.

So Dramatic Ignorance attains two goals. First, it strips parties of knowledge of their own attributes, circumstances, social positions, degree of risk aversion, and conceptions of the good. It also excludes knowledge of one's 'native endowments', strength, intelligence, and bargaining savvy. ${ }^{115}$ It prevents the parties knowing whether they will be faster in collecting debts, or friendlier with the debtor, or particularly badly hit by the debtor's insolvency. This is the 'obscuring' role of Dramatic Ignorance.

Second, it ensures that what is essential to the 'true and genuine person' is left behind. Here is how this is achieved. Note first of all that the choice position is 'a case of pure procedural justice.' This means there are no external criteria, independent of those specified by the ACM, by which the fairness or justice of the chosen principles can be judged. Because the affected parties themselves, 'symmetrically situated' in the choice position, ${ }^{116}$ are to choose principles, the choice is taken to be that of principles for free and equal citizens. This also indicates how the choice position models the parties' liberty, equality, and reasonableness. That citizens affected by insolvency issues are to be regarded as free is modelled by the rationality of the parties in the choice position. ${ }^{117}$ In this position, parties

\footnotetext{
$114 P L, \mathrm{p} 24$.

115 Ibid, p 25.

116 Ibid, p 24.

117 PL, p 104.
} 
anticipate the various conceptions of the good they might turn out to have, and are able rationally to provide the means for enabling any such conception to be pursued through their choice of insolvency principles. That the choice position is a case of pure procedural justice models the citizens' rational autonomy. They are bound by nothing except what they themselves would specify as free and equal persons. ${ }^{118}$ That citizens are equal is modelled by the choice position placing all the parties symmetrically. As long as one has the capacity to form a conception of the good, and the capacity to be moved by considerations of reciprocity, one is admitted to the choice position, and there has equal influence on the choice of principles. ${ }^{119}$ The symmetry of the choice position also models citizens' reasonableness, and Dramatic Ignorance means the parties do not know who they will turn out to be and what would be their conception of the good. This ensures the principles are impartially chosen and fulfil the requirements of reciprocity. ${ }^{120}$

Parties in this state, while not omniscient, are also regarded as having all the knowledge they need to reach decisions on insolvency issues, including knowledge of social, economic, and political theory. They also have access to all the relevant empirical data then available. (More accurately, of course, the parties have all the knowledge materially and intellectually accessible to the person expounding the ACM.) That the parties are suitably knowledgeable, and that they are free, equal and reasonable, is ensured through the 'exaggerating' role of Dramatic Ignorance.

\section{c. The choice position}

It is time to deal with two objections made to the construction of the choice position. Each of these objections is ultimately spurious, and in arguing against them, one ends up with a richer appreciation of the fundamental ideas in which the ACM is grounded. ${ }^{121}$

The first objection is to Dramatic Ignorance. It was pointed out in the first part of this paper that the Creditors' Bargain is based on a contractarian model developed by Richard Posner. Jackson takes from Posner the ingredients which go into the construction of the Creditors' Bargain. A very important one of these is Natural Ignorance. Parties in the Creditors' Bargain know who they are and what they want, but not how their transactions with the debtor are going to turn out. Posner gives two reasons for preferring Natural Ignorance to what here has been called Dramatic Ignorance. ${ }^{122}$ The more interesting objection concerns the sort of claims the parties in Dramatic Ignorance must take into account. Since parties do not know their own attributes, they do not know whether they would turn out to be talented and hardworking, or lazy and unproductive. Given this factor,

\footnotetext{
${ }^{118}$ Ibid, $\mathrm{p} 72$.

${ }^{119}$ Ibid, pp 79, 305.

${ }^{120}$ Ibid, pp 104, 305-6.

121 One quite hopeless ground for criticism can be dismissed straight away. Carlson 'Philosophy in bankruptcy' (1987) 85 Michigan LR 1341, 1344, describes theories based on conditions similar to Dramatic Ignorance as 'ineffective' because 'One cannot really fathom a time when people are so disembodied from their histories that they have no idea whether they are more likely to be investment bankers or widows.' This sort of criticism has force against any attempt to rescue the Creditors' Bargain by depriving all creditors of knowledge of who they are in the ex ante position. But against the ACM, this objection would be bizarre and entirely beside the point. Dramatic Ignorance is based on moral considerations, as explained in the text, and is not supposed to be a description of some actual 'historical' state, amnesic or amnestic. This issue is taken up again in Section 13, below.

122 The first deals with the preference functions of those regarded as being in Dramatic Ignorance. Rawls deals with this problem by stipulating people in this state want certain 'primary goods' no matter what else they want, and the model developed here makes the same assumption about the insolvent's assets. This is discussed below.
} 
Posner claims any choice position based on Dramatic (rather than Natural) Ignorance 'opens the door to the claims of the unproductive.' In order to look after their interests if they do turn out to be unproductive, the parties would have to ensure the rules chosen in the choice position gave as much importance to the claims of lazy and unproductive people, as those of diligent and productive ones. '[T]he choices of the unproductive are weighted equally with those of the productive.' The result is objectionable, concludes Posner, because it 'obscures the important moral distinction... between capacity to enjoy and capacity to produce for others' ${ }^{123}$ While productive people have both, unproductive ones only have the former.

This objection reveals rather nicely the extent of Posner's misunderstanding of a true Rawlsian choice position of the sort sketched out here. Note first of all that Posner seems to think parties in that position, like the parties in the ex ante position of the Creditors' Bargain, are doing no more than expressing preferences. Since these preferences are shaped by nothing but one's whims and self-interest, parties can express any preference without restriction. But of course this is wrong. Because of the construction of the choice position, parties must act reasonably. Here, they are not merely expressing preferences, they are selecting principles of justice. In order to do that, they must propose principles others can reasonably accept. ${ }^{124}$ Further, 'in selecting principles of justice the parties must... take into account the consequences of those principles being mutually recognised and how this affects citizens' conceptions of themselves and their motivation to act from those principles. ${ }^{125}$ Parties are also rational. They realise that (given Posner's assumptions) unproductive people can only be sustained through the efforts and work of productive people.

Two conclusions follow. First, if there are too many unproductive people in any society, not enough would be produced to sustain everyone and that society would collapse. In order to ensure this does not happen, the principles chosen to govern everyone equally would be likely to discourage rampant un-productivity. And second, citizens in actual society are constructively regarded as fully co-operating members of society. Co-operation is based on reciprocity, and on not making demands against others which one would be unwilling (though able) to meet oneself. For some people to require others to work so as to sustain them while not reciprocating in kind is to make an exploitative demand. Reasonable persons do not make exploitative demands. And it undermines citizens' motivation to uphold principles if they regard them as exploitative. So exploitative demands would not be enshrined in the principles of justice selected in the choice position. Put the two factors together and it should be clear Posner is wrong in thinking the claims of the unproductive would be given equal weight to those of the productive. ${ }^{126}$

Note also that in the specific corporate insolvency context, the assumption of rationality itself rules out paying heed to the claims of the unproductive. Companies are created to attain certain ends. '[People] usually become involved with companies with the intention of improving their economic position. [So they would want] to have their affairs governed by rules which are designed to foster efficient outcomes. ${ }^{127}$ Within the limits set by society (for example through environmental standards, laws on labour rights, product

\footnotetext{
23 Posner 'Efficiency', pp 498-9.

$124 P L, \mathrm{p}$ xliv.

125 Ibid, p 104

126 Obviously, the argument is based on the assumption that 'unproductive' people are capable of being productive but choose not to be. As for people who are unproductive simply because they are unable to work (due to disability, etc.), parties selecting general, society-wide principles (not just those applicable in corporate insolvency situations) would anticipate they might turn out to suffer from such incapacity, and would choose principles accordingly. Such principles might lead to a welfare state of some description. Discussion of this is of course beyond the scope of this article.

127 Cheffins, Company Law: Theory, Structure and Operation (Oxford: Clarendon, 1997), pp 305-6.
} 
liability and misrepresentation etc.), then, companies must maximise profits for their shareholders (or otherwise maximise shareholder value). ${ }^{128}$ If charitable, they must maximise the output for charitable purposes. Rational parties do not tolerate knowing unproductivity in ventures such as these, since un-productivity is the antithesis of the very reason why companies exist. And if the claims of the unproductive will not be tolerated in the company's solvency, there seems little reason why they should be in its insolvency. Even in the very unlikely case where someone creates a company in order to avoid having to work hard, that person's claims against the company are at an end once it is insolvent. The company's assets belong to the creditors, ${ }^{129}$ who are unlikely to want to indulge his desire for leisure in deciding what they should do with those assets. Rational parties anticipate all this while deciding which principles to choose. Because of rationality and reasonableness, then, Posner's objection to Dramatic Ignorance turns out not to be effective.

Now for the second objection. Recall that by the time the relevant parties reach the choice position, they have been rendered (dramatically) ignorant of any knowledge of personal attributes or conceptions of the good. By virtue of being symmetrically situated in the choice position, the parties can not choose other than to protect their equality:

The right of each[] to be treated equally without regard to [their] person or character or tastes is enforced by the fact that no one else can secure a better position by virtue of being different in any such respect. ${ }^{130}$

Parties seek to further their self-interest in choosing the principles to govern insolvency situation, but 'The state of ignorance in the [choice] position is so shaped that the antecedent interest of everyone must lie [] in the same solution. ${ }^{131}$

This ensures agreement. But (it might be asked) since all the parties have no knowledge of who they are, of what they value, or of their own advantage, how are they to decide which principles would better serve their self-interest?

This objection is not difficult to meet. If the choice situation were designed to settle principles of justice for all aspects of society, then the lack of knowledge by the parties of their own conception of the good might pose serious problems. The parties in Dramatic Ignorance know they have a capacity to have, develop, and revise some such conception. Once out of Dramatic Ignorance, they will discover what they value. But before that point, how do they decide what set of principles best protects and furthers interests they do not then know they have? One popular response is to stipulate parties want certain 'primary goods'. These are 'all-purpose means normally needed for...pursuing conceptions of the good with widely different contents. ${ }^{132}$ In the general society-wide context, the primary goods are defined to include basic rights and liberties like 'freedom of movement, free choice of occupation protected by fair equality of opportunity..., income and wealth' etc. So parties

128 Piercy v S Mills \& Co [1920] Ch 77; Hogg v Cramphorn Ltd [1967] Ch 254; Bamford v Bamford [1970] Ch 212; Charterbridge Corporation Ltd v Lloyds Bank Ltd [1970] Ch 62; see also Rackham v Peek Foods Ltd [1990] BCLC 895 and Aveling Barford Ltd v Perion Ltd [1989] BCLC 626.

129 For the purposes of this article, this should be taken to mean no more than that, under the general law, creditors have priority over shareholders, and that insolvency law needs a reason to depart from this position. See further Kinsela v Russell Kinsela Property Ltd (in liq) (1986) 4 NSWLR 722, 730, per Street CJ; quoted with approval by Dillon LJ in West Mercia Safetywear Ltd (in liq) v Dodd and another [1988] BCLC 250, 252-3; Morse (principal ed.), Palmer's Company Law (London: Sweet \& Maxwell, 1992) (25th ed), para 8.506, and the authorities therein cited; finally, see Insolvency Act $1986, \mathrm{~s} 214$.

${ }^{130}$ Dworkin 'Position', p 49.

131 Ibid.

${ }^{132} P L$, pp 75-6. 
judge the proposed principles on the basis of how effectively they ensure a distribution of primary goods which would serve the sort of conceptions of the good they might turn out to have. $^{133}$

It is tempting to follow these general theories in stipulating a fairly abstract primary good the parties faced with the peculiar circumstances of insolvency are regarded as desiring in the choice position, no matter what their conception of the good. For example, Korobkin asserts parties in the choice situation are to be regarded as desiring 'the best possible position to influence the actions and decisions of the financially distressed corporation'. ${ }^{134}$ The ACM resists the urge to remove too far from the context and actual circumstances of corporate insolvency the stipulated choice of what all parties are presumed to want. In society generally, citizens pursue a myriad of objectives, aims, goals and desires. They have immensely varied conceptions of what makes life worth living. In choosing principles of justice to regulate all of society, it is right to regard them as wanting fairly abstract rights of the sort mentioned above, because only such abstract rights would serve the pursuit of most conceptions of the good.

But in insolvency circumstances, the 'primary good' all relevant parties, no matter what their conception of the good must in the final analysis want, is the insolvent's assets. Parties in the choice situation know, after all, that by definition it is the fact of these assets being insufficient to meet the debtor's liabilities, which gives rise to all situations peculiar to insolvency. Tort victims, secured and unsecured creditors, and shareholders, all want to ensure the insolvent's assets are used so as to benefit them. Employees who claim their jobs should be protected in a situation somehow peculiar to corporate insolvency are claiming precisely the same right. They wish the firm's assets to be deployed so as to ensure they will continue to enjoy the benefits associated with those assets being thus deployed. This would include having a workplace they have invested in and value, their fruitful association with work-mates, and of course their salaries, wages and bonuses. Directors who become subject to wrongful trading claims have similarly deployed the insolvent's assets to their own ends, rather than in trying to minimise harm to the company's creditors. Members of a community who claim to be affected by peculiar insolvency circumstances again want the firm's assets to be deployed so as to provide them all the benefits they claim they would lose because of insolvency.

Parties in the choice position know, then, that no matter what their conception of the good turns out to be, and no matter how they turn out to be related to the insolvent firm, what they would want is the insolvent's assets. They therefore judge the acceptability of all proposed principles by reference to how they ensure the parties would have access to those assets, no matter who they turn out to be.

It should be clear by now why the principles chosen in the choice position produce normative force and are to be considered binding. The choice position includes conditions as to the nature of the parties, and on their state of knowledge 'that we do in fact accept [as normatively attractive]. Or if we do not, then perhaps we can be persuaded to do so by philosophical reflection.' Each element of the choice position can be supported from within the political and legal culture of this society. ${ }^{135}$ Any party affected by a peculiar insolvency situation can enter the choice position at any time by imposing on its own reasoning the constraints which define the choice position, and by acknowledging that binding principles of law must be of general application, not merely suitable for a particular transaction. It can then ask whether it accepts the principles binding it as fair. The choice position is 'a device of

\footnotetext{
133 Ibid.

134 'Foundations', p 571.

135 Theory, pp 21-2.
} 
representation [and] serves as a means of public reflection and self-clarification. It helps us work out what we now think, once we are able to take a clear and uncluttered view of what justice requires when society is conceived as a scheme of cooperation between free and equal citizens'. ${ }^{136}$

\section{THE PERFORMANCE}

It has been pointed out that the stay on individual actions by unsecured creditors has been a part of bankruptcy and insolvency law, as it were, from the day that there has been such a law. The collective regime defined by the stay is the most central and unchallenged aspect of the process of winding up companies. The stay on unsecured claims is a 'provisional fixed point', then. That it should exist and be part of insolvency law is one of our 'settled convictions' about this area of the law. ${ }^{137}$ We feel confident, and can agree, that independent action by the unsecured creditors of an insolvent should be stayed, whether or not we agree on any other aspect of the insolvency regime. Very persuasive reasons indeed would have to be produced to convince us the stay should no longer be part of insolvency law. Till such reasons are forthcoming, any explanatory theory about the insolvency regime should be able to account for the stay. If it does not, it can not claim to be an account of this regime. We condemned the Creditors' Bargain precisely because it fails this test. Does the ACM do any better?

It is suggested the very reasons which led to the failure of the Bargain heuristic descriptively to account for the automatic stay, must also compel the conclusion that the ACM succeeds. The Real Parties premise of the Creditors' Bargain meant unequal parties would either not accept a stay at all, or would accept a rule which reflected the inequality in their debt-collection and bargaining skills. And the lack of any specific ex ante point at which the counterfactual agreement was to be concluded meant that the self-interest of the parties, which drove the agreement, would be different depending on when (temporally or as a function of the parties' knowledge of personal attributes) it was ascertained. It was noted that Jackson's strategy for dealing with these issues -- the assumption that all ('real') creditors are identical -- gave the game away by violating every single condition of his model ('real world parties', 'actual endowments', 'natural ignorance').

The ACM is very different. It first ascertains who should be included among the parties who would be asked to accept or reject the automatic stay. It does this by asking whose rights and prospects are affected by the automatic stay in a way peculiar to the circumstances of corporate insolvency. These parties include all the insolvent's shareholders, and all its unsecured creditors, consensual, non-consensual, adjusting and non-adjusting. The collective regime defined by the automatic stay compulsorily deprives these parties of the ability to proceed against the debtor company in a way unique to insolvency. The discussion in Sections 8 and 9 above shows it remains to be demonstrated that any other party is thus affected by the automatic stay. In addition, for the shareholders, insolvency proceedings might confirm at law what might already be the case in fact, that there being insufficient assets to pay off creditors, they (the shareholders) are no longer the residual claimants to the company's assets. Again, this is unique to insolvency situations.

\footnotetext{
${ }^{136} P L, \mathrm{p} 26$; emphasis added to indicate a standpoint in actual society, free of the artificial constraints of Dramatic Ignorance.

${ }^{137}$ Ibid, p 8.
} 
These parties are then stripped of any knowledge of personal attributes and put in a state of Dramatic Ignorance. The model justifies this by pointing out that in proposing and accepting rules of justice, it is morally irrelevant whether a party is faster or more effective in collecting debts, or whether it is wealthier and better able to monitor the debtor, as long as the interests of all such parties are given equal and fair consideration. This is ensured by the construction of the choice position. Here, all the parties seek to further their antecedent selfinterest, constrained by considerations of reciprocity. Since the parties do not know who they will turn out to be once the state of Dramatic Ignorance is removed, they must equally take into account the interests of all the actual people they might find themselves to be.

In the choice position, the parties realise that the insolvency of the debtor leads to a common pool problem in the way described in the first part of this article. All the creditors would have to expend resources monitoring the debtor and racing for its assets, and the race might lead to a value-destroying break-up of the debtor's business. The parties in the choice position also anticipate at least some real-life creditors would be risk averse. The utility of such creditors would be increased by assuring them a lower but more certain return on their loans than would be the case under the individualistic non-insolvency regime. ${ }^{138}$ Parties would also realise that shareholders (who by definition have agreed to postpone their claims to those of the company's creditors if there is doubt about the company's solvency) would benefit from maximising the value of the collective pool of the company's assets. Those assets might be sold off together as a going concern if that is how they are most valuable. Alternatively, they might be disposed of piecemeal. Whatever the case, a procedure which can review all the possibilities and settle on the optimal result would be more likely to ensure shareholders receive any potential surplus from the sale. In addition and as noted, a collective liquidation regime minimises the uncertainty inherent in any individualistic post-insolvency regime about the creditors' respective positions in the queue for the debtor's assets. This would be reflected in the interest charged by adjusting creditors on their loans during the company's solvency. Since the company would have to pay less on financing its debts, more would be available for disbursement to the shareholders. Realising this, a party in the original position would be willing to accept the automatic stay even though they might turn out to be a shareholder of the company rather than a creditor.

Note another very important consideration for the parties in the choice position. They anticipate that they might turn out to be a creditor particularly vulnerable to, and badly affected by, the debtor's insolvency. Certain employee-creditors arguably are an example, since they are usually dependent solely on their salaries, might be unable to diversify by working for more than one employer, might have no insurance because they are not able to join a trade union which would buy such insurance for its members, and might be unable quickly to find work on losing their job. It might be possible, in the choice position, to make an argument that such creditors deserve more protection in the insolvency forum than a welldiversified bank-creditor, say. But the parties in the choice position accept a distinction that will be referred to as that between immunity and priority. It might be that employee-creditors deserve priority over bank-creditors in being paid out of the insolvent's estate for the reasons mentioned. But that is a separate question from whether employee-creditors should be immune from having to give up individual debt-collection rights and being forced to participate in the collective regime characterised by the automatic stay. Even if employee claims should be met before bank claims, it would be in the collective interest of employees and banks alike to maximise the pool of assets from which all these claims would be met, in

${ }^{138}$ See also Westbrook 'The globalisation of insolvency reform' [1999] New Zealand LR 401, 406-7. 
whatever order. ${ }^{139}$ The question of how the insolvent's assets should be distributed can be and often is a different question from how they should be deployed. ${ }^{140}$

Parties also anticipate some of them would turn out to be creditors of the sort who are not benefited by the automatic stay in most individual transactions. This would be the case with creditors who are repeat players, are well-diversified, and have the resources to position themselves advantageously for the individualistic race for the insolvent's assets. ${ }^{141}$ But in the choice position, the principles laying down the automatic stay would still be chosen. Parties of course do not know who they will turn out to be. They might turn out to be the type of creditor who could do better in the individualistic race, but they might not. Faced with this uncertainty, the parties would put themselves in the position of both sorts of creditor. They would ask what their prospects would be under the collective regime marked by the stay. This regime enhances the value of the pool of assets available collectively to all creditors. So to grant any type of creditor immunity from having to participate in this regime is to impose costs on all the creditors as a group. But this is not decisive for the parties. Suppose the collective regime would threaten the vital interests of a creditor of type X. Parties anticipate they might turn out to be a creditor of this type. So they would not risk leaving such vital interests unprotected simply because that enhances the pool of assets available to all.

All the parties in the choice position together might accept a smaller pool of assets, then, if the only alternative is to inflict significant harm to the prospects of one type of creditor. Each party has some incentive to agree to this, because each party has an equal chance (as against each other party) of turning out to be such a creditor. If the automatic stay does turn out to threaten some type of creditor in this way, the parties would contemplate giving that creditor immunity from it. But in fact, the type of creditor who could do better without a stay is precisely the sort best able to cope with the effects of the stay if it is imposed. Well-financed repeat players can anticipate the effects of the stay on their own prospects, and can adjust their lending terms or their interest rates accordingly. They are also likely to be well-diversified. Other types of creditor who have influence over the debtor even though they are not repeat players (e.g. directors who have leant to their company) ought to be well-informed about the debtor's prospects, can control the debtor's actions, and can still adjust the terms of their loans. In either case, the automatic stay does not threaten any of their vital interests. And again, it would still be possible for any party to make an argument that, within the collective regime, some types of creditor should be given priority over other types.

It is important to be clear about the differences between the reasoning of the parties in the choice position, and of the creditors in Jackson's ex ante position. In the latter, creditors who can do well under the individualistic debt-collection regime would want that regime. They do not care about the size of the common pool of assets. As long as they are paid, they do not mind if their activities have an adverse effect on others. For repeat players, the accumulated expertise of collecting debt and the associated economies of scale are tools to be used to seek the best position for the individualistic race. Diversification is the way of ensuring even if one does not win a particular race, the harm thus done can be remedied by winning other races. In this way, these creditors can pass on the costs of their race for the insolvent's assets to all the other creditors, and being motivated only by self-interest, would indeed do so.

\footnotetext{
139 Compare IA, ss. 175 and 386, and Sch. 6. But note that the employee-creditor example is merely illustrative. No position is taken in this article on the priority of employee claims in corporate insolvency.

${ }_{140}$ Carlson 'Philosophy', p 1352, makes a similar point. For a qualification, see Mokal 'Wrongful trading'. The argument is taken up again in Mokal 'Priority as Pathology'.

${ }^{141}$ See the first part of this article.
} 
For the parties in the choice position, on the other hand, there are no 'others' to whom these costs can be passed. All the parties equally must take them into account. The stay seems to protect the interests of parties (especially one-off transactors) who as a group simply would not have any chance of competing against repeat players in the individualistic race, and (for non-consensual creditors) might have had little control over the terms of the loan. And the parties in the choice position know that the creditors worst affected by the automatic stay (creditors who are not risk averse in any particular transaction because they are repeat players, and those having insider knowledge of the company's prospects, etc.) have the ability to diversify and to adjust interest rates and other terms of the loan to compensate for the effects of the stay. This assures them such creditors would not suffer harm to their vital interests if they are indeed subjected to the collective regime.

So in the choice position, and reinforced by understanding the priority/immunity distinction, all the parties would select the automatic stay on unsecured claims.

\section{THE DENOUEMENT}

It is time to note the implications and consolidate the results. The ACM is a descriptive and analytic device. By focusing on insolvency law as a scheme of fair co-operation in insolvency situations, it helps illuminate the deep structure of the automatic stay. It shows how all the relevant parties, motivated by antecedent self-interest and considerations of reciprocity, would consent to the collective regime defined by the stay. And importantly, it also indicates focusing on the stay in isolation provides an incomplete picture. Arguably, parties in the choice position might find the automatic stay in their interest if they turn out to be a particular type of creditor only if such creditors are assured a certain priority within the collective insolvency regime.

The ACM is also a justificatory device. It sees all parties as free and equal, reasonable and rational. By removing factors which are morally irrelevant in proposing and accepting principles of justice, the model ensures the principles chosen are fair and just. As a result, the principles recommended by the ACM can be seen as having been consented to by 'true and genuine' persons. They are justified because they are chosen in exercise of the full political autonomy of all those they will govern:

[Full] autonomy is realized by citizens when they act from principles of justice that specify the fair terms of cooperation they would give to themselves when fairly represented as free and equal persons. ${ }^{142}$

Finally, and as promised (in Section 3 above), a word to the sceptic who is tempted to make the innocent claim that the ACM is just another form of the Creditors' Bargain. It might be said the 'only' difference between the two is that the former employs Dramatic Ignorance. The Creditors' Bargain is unsuccessful because it seeks to ascertain the counterfactual consent of creditors who are aware at that time of who they are. This ensures either that no agreement would be reached, or if reached would be exploitative and oppressive of weaker parties. But the solution is straightforward. Simply deprive the creditors of the Creditors' Bargain of any knowledge of who they are, and at a stroke, one solves all the problems which beset that model. Someone who does take this view might wonder why the intelligent people who have been writing in the Creditors' Bargain tradition for the last two decades have not

${ }^{142}$ PL, p 77. 
thought of this simple move before! Why for example does Jackson base the Bargain model on Real Parties in Natural Ignorance? This means he is forced to assume later that all ('real') creditors are homogeneous, and then has to go to torturous lengths to argue even nonhomogeneous creditors would accept the automatic stay. ${ }^{143}$ Surely a simpler way would have been to stipulate that all creditors are to be rendered homogenous by being deprived of any knowledge of personal attributes at the time that their consent is notionally sought. But neither Jackson nor any other expositor of the Bargain has done that.

The answer, of course, is that the move is not simple at all. What divides the Creditors' Bargain and the ACM is not a narrow slit consisting of dissimilar types of uncertainty (the two versions of Ignorance). It is a wide chasm of profound philosophical differences. This can be made clear in the following way. Suppose S, a scholar sympathetic to the Creditors' Bargain, suggests the Bargain model should drop Natural Ignorance in favour of Dramatic Ignorance. So the notional consent of creditors should be sought after stripping them of any knowledge of what sort of creditor they are (voluntary or involuntary, bank or employee, etc.). How would S justify this move? Let us assist by suggesting four possible ways. First, the move from Natural to Dramatic Ignorance might be supported by saying this is the only way for the Creditors' Bargain to predict the automatic stay on unsecured claims. But surely this just begs the question. If the move is nothing more than the rigging of the model to attain the desired result, it is intellectually dishonest. What is required is a justification, and the need to save an otherwise failing theory is not an attractive justification.

Second, S might simply decline our demand for a justification for the Natural to Dramatic move. He might reply, for example, that it is just convenient to base the Creditors' Bargain on Dramatic Ignorance. But real creditors are unlikely ever to be unaware of who they are and of their conceptions of the good. ${ }^{144}$ As already mentioned, they are entitled to ask why the notional choices of non-existent creatures who seem so different from them should have any significance for them. Why should real creditors accept as fair or binding rules supposedly chosen by creatures who are figments of S's imagination? S has no response.

He might now claim all he is concerned with is the Bargain model's ability to predict and explain the collective liquidation regime. Making the assumption that creditors are unaware of personal attributes at the time their consent is sought allows him to do that, and he might state that he feels no obligation to justify that regime to those subject to it. Now of course the refusal to justify laws to those governed by them is rather repugnant to democratic societies, and might lose the Creditors' Bargain some support. Laws must be legitimate, not just imposed. But even in the claim that $\mathrm{S}$ can predict and explain the automatic stay, he would be only half-right, half of the time. By arbitrarily adopting Dramatic Ignorance, his model would certainly have acquired the power to predict the automatic stay. But it still can not explain it. S's position now can be compared to that of a young child who has learnt to predict that by pressing a switch on a torch light, she can produce a beam of light. But the child can not assign any meaning to the fact of pressing the switch. She can not explain the role of the internal wiring, the batteries, the bulb, the plastic case, the reflectors, etc. And if pressing the switch no longer works because the batteries run out, or the bulb fails, or water seeps through the case and short-circuits the wiring, the child would be at a loss to suggest anything useful. Such would be the case with S. He could baldly state that by using Dramatic Ignorance, one could predict that insolvency law would stay all unsecured claims. But he can not assign any meaning to the use of these strange Dramatically Ignorant creatures, seemingly so different from real-life creditors. Nor can he employ the principles which justify use of

\footnotetext{
${ }^{143}$ See the first half of this article.

144 This is where Carlson's comments 'Philosophy', p 1344, concerning widows and investment bankers, noted supra, are relevant.
} 
Dramatic Ignorance to criticise the liquidation system or suggest reform, should circumstances change and the system is no longer appropriate. But surely we are entitled to expect more illumination from insolvency law scholars than we do from the child with the torch.

Finally, though, S might produce a more satisfactory response. He might reply that it is right and proper for those selecting binding rules to be required to do so impartially, and that Dramatic Ignorance achieves precisely that. This would be a good justification, and the beginning of the process which leads to the ACM. But in saying that, $\mathrm{S}$ would also decisively have rejected the Creditors' Bargain. His suggestion now is based on the idea that each person matters equally. This needs to be given substance. The ACM accomplishes that by regarding as equal all those who have the moral capacity to form and revise a conception of the good, and the moral capacity to be moved by considerations of reciprocity. These two moral powers are accepted as logically prior to the hypothetical contract, and are essential to qualify for participation in it. The choice position as defined by Dramatic Ignorance is appropriate because it gives substance to the idea of moral equality, and by extension, to the right of all moral equals to equal care and concern in the selection of binding principles.

But these notions are profoundly alien to the Creditors' Bargain. As a mutual advantage theory, the model sees 'justice' as an extension of brute rational choice. ${ }^{145}$ Its aim is to prove one could manufacture the principles supporting the insolvency regime by appealing to nothing but rational self-interest. So the Bargain is based on nothing but preferences, and these are shaped by nothing but one's self-interest. Since the Bargain model assumes it can do without any reference to morality, it can make no appeal to fairness. It has no conception of pre-existing moral powers. It perceives 'no moral equality underneath our natural physical inequality' ${ }^{146}$ The Bargain here is not used to give substance to more abstract rights which are prior to it. Rather, it is used in an effort to create rights where none existed before. ${ }^{147}$ The Bargain model can not explain the move of stripping away the individuality of the parties during the bargaining process, about why the parties should accept anything decided in Dramatic Ignorance. ${ }^{148}$ And it simply has no theory or notion about what - if anything - would be left behind once the parties' individuality has been thus removed. ${ }^{149}$ So Dramatic Ignorance is forbidden to this model. The use of Dramatic Ignorance in the ACM requires significant philosophical commitments. ${ }^{150}$ But if it were to make those commitments, the Creditors' Bargain would cease to be what it is, a model based on the (false) claim of moral neutrality. ${ }^{151}$ Expositors of the Bargain model want to make that claim, and so can not make those commitments. It should be clear, then, that in both premises and conclusions, the Creditors' Bargain and the ACM are worlds apart. ${ }^{152}$

\footnotetext{
145 Contrast Gauthier Morals, pp 243-4.

146 Kymlicka, Philosophy p 126, about mutual advantage theories in general.

147 Contrast Gauthier Morals p 222.

148 See Gauthier's own attempt in Morals Ch VIII, especially pp 265-7.

149 See Gauthier Morals p 256: "The real individual... has his own particular and defining characteristics -- capacities, talents, attitudes, preferences. He acts taking these as given, and his rationality is expressed in his endeavour to maximize the fulfilment of his preferences given his capacities and other traits of character, in the circumstances, whatever they may be, in which he finds himself... [T] here is no other conception of the person involved." This is, as it were, a textbook definition of Natural Ignorance; it is also the creed of mutual advantage theories like the Creditors' Bargain.

150 As already noted, of course, the ambit of the claims made by the model are restricted to a particular type of society. This, it should be made clear, is motivated not by any belief in moral relativism on this author's part but only by the desire to avoid the argument being intolerably lengthy.

${ }^{151}$ See eg Carlson 'Philosophy', pp 1354 and 1364 fn. 79 for one view of why the Bargain model is not neutral.

${ }^{152}$ The final sentence paraphrases Kymlicka, Ibid, p 128.
} 


\section{CONCLUSION}

This article pits the long-established Creditors' Bargain construct against a model that is developed in the second half of the article. It puts the Creditors' Bargain through its paces, examining its fundamentals, rationale, and construction. The Creditors' Bargain is unable to describe a central part of insolvency law, is arbitrary and incoherent, and lacks justificatory force. It tries to legitimate the automatic stay by suggesting actual creditors at a hypothetical pre-transaction stage would agree to just such a rule. But it fails.

The confusion inherent in the Creditors' Bargain makes it clear that:

[One] cannot merely invoke the fact that under circumstances $\mathrm{C}$ agent $\mathrm{A}$ would prefer option O. One must explain the propriety of describing the circumstances in a particular way, of attributing particular characteristics and interests to the agents in the choice position, and of giving them a particular menu of options. Perhaps this would take legal writers too far into the muddles of moral philosophy. If so, it might be the better part of valor to eschew appeal to arguments of this kind. ${ }^{153}$

All that is true, and the warning is apt. But a principled analysis and justification of this central feature of insolvency law must surely by sought. So the ACM sets off to avoid the faults of the Creditors' Bargain. It decides on the menu of options to present to the parties in the choice position by asking, 'What makes insolvency law special?' It defends the characteristics it attributes to the parties by claiming the legal and political culture of society demands citizens be considered free, equal, and reasonable, when consulted on the design of institutions meant to govern them. And it justifies the propriety of defining the choice position in a particular way by pointing out that the choice of principles should not be influenced by morally irrelevant features and considerations of legislators, who in turn should act rationally in choosing such principles. It is therefore claimed the resulting model can analyse and justify corporate insolvency law and its longest-standing feature.

${ }^{153}$ Brudney ‘Consent', p 262 (footnote omitted). 